\title{
Historical ethnobotanical review of medicinal plants used to treat children diseases in Romania (1860s-1970s)
}

\author{
Madalina Petran ${ }^{1}$, Dorin Dragos ${ }^{2,3}$ and Marilena Gilca ${ }^{1 *}$
}

\begin{abstract}
Background: Romanian ethnopediatrics has a long history of medicinal plant use. The main objective of the present review was to identify, collect, systematize, and prioritize the available bibliographical data related to medicinal plants traditionally used to treat various pediatric diseases in Romania during the 1860s-1970s.

Methods: Information was mainly obtained by manual systematic search in various relevant historical works focused on the traditional use of medicinal plants in Romania (1860s-1970s), found in the Archives of Romanian Academy Library and National Romanian Library.

Results: A total of 153 medicinal plants belonging to 52 families were identified as having ethnopediatric significance. The plant traditional indications, targeted body systems, parts used, and way of administration were provided. We have also proposed one index (expressed as percentage) in order to assess the ethnopediatric applicability area of species: ethnopediatric relative therapeutic versatility (ERTV), which was calculated on the basis of the number of distinct uses mentioned for a species. The species identified to have the highest ERTV scores were Dryopteris filix-mas (100\%), Gratiola officinalis (85.71\%), Allium sativum (71.42\%), Eryngium planum (71.42\%), Juglans regia (71.42\%), Matricaria chamomilla (71.42\%), Plantago major (71.42\%).

Conclusions: The present study exposed for the first time to the international scientific community important ethnopediatric information contained in several local Romanian bibliographical resources that could guide the local and international researchers towards new directions of plant valorization.
\end{abstract}

Keywords: Medicinal plants, Ethnopharmacology, Pediatry, Ethnopediatry, Children, Romania

\section{Introduction}

Romanian ethnomedicine and ethnopediatry in the European context-past and present

The majority of the European ethnopharmacological knowledge has its roots in the Greek and Roman cultures, being essentially influenced by works of Dioscorides, Pliny the Elder, Galen, Theophrastus, and Hippocrates [1-3]. Scientists revealed a remarkably

\footnotetext{
* Correspondence: marilenagilca@gmail.com

'Department of Functional Sciences I- Biochemistry, Faculty of Medicine, Carol Davila University of Medicine and Pharmacy, Bucharest, Romania Full list of author information is available at the end of the article
}

consistency between Dioscorides's De materia medica and later European pharmacopeia, Dioscoridean tradition lasting through the nineteenth century with only insignificant variation [4], or even up to the birth of modern pharmacology $[2,3]$. While in the Western and Central Europe, herbalism played an important role in drug discovery beginning with the nineteenth century [5]; in Eastern Europe, the exploitation of the ethnopharmacological tradition was hindered by several challenges:

(a) Vicissitudes related to the social-political-economic environment in those countries belonging to the 
previous communist bloc, including Romania (e.g., marginalization of experts originating from bourgeois families, and therefore considered "enemies of the regimen," informational censorship, lack of interest in supporting scientific research and preservation of national cultural heritage, lack of financial support for libraries-Romanian Academy Library was considered too "bourgeois" by the communist regimen, and therefore was replaced in 1955 by State Central Library) [6].

(b) Other types of challenges: inaccessibility of many of the texts on medicinal plants preserved in locations with limited access to the public (e.g., monasteries with a strict daily schedule, archives not open for the public), reduced legibility of certain manuscripts (lost parts, deterioration in time, low quality of print or indecipherable handwriting), some texts are written in old languages and are not yet translated (e.g., many Romanian manuscripts found in the National Archives are written in old Slavonic language) or investigated by an interdisciplinary team (historians, linguists, anthropologists, botanists, etc.), old terminology with obscure meaning for the contemporary scientist, lack of certainty about the identity of taxa (e.g., only vernacular names or obsolete Latin names), difficulties of communication with informants (e.g., monks who are not allowed to take in faceto-face interviews, suspiciousness of informants caused by superstitions, or desire of the respondents to protect the "secrets" of their medical knowledge, sometimes transmitted only within the families) $[4,7-11]$.

Some of these aspects might have contributed to the fact that the ethnomedical knowledge of Eastern European countries remained in a certain degree localized, and isolated from the rest of the world [5, 12]. On the other side, due to this isolation and other factors as well (e.g., slower economical development, preservation of small-scale agro-pastoral activities as main economical subsistence tool in rural area [13], continuity of traditional practices in monastic communities, known for their principles of living in harmony with the environment), this part of Europe may still possess a tremendous reservoir of traditional ethnomedical knowledge $[13,14]$. For instance, many Romanian Christian Orthodox monasteries are located in the forests, or faraway from inhabited areas, and cultivate principles similar to those of environmentalist sustainability (e.g., respect for Creation/Nature as a manifestation of God, protection of natural resources (gifts of Creation) for future generations, vegetarianism, stability and discipline, etc.) [15]. The monastic community from the
Vânători-Neamț Natural Park, which is recognized as the second largest in Europe, after that of Mt. Athos in Greece, is such an example $[15,16]$.

It is also known that prior to the twentieth century, European medicine was based mainly on Mediterranean plant-derived drugs (with some additions from the Middle East, Asia, and the Americas) [4], the ethnopharmacological tradition originating in the rest of Europe, such as Eastern European countries including Romania, being underexploited at that time, as well as nowadays.

Many scientists claim that exploring historical texts in a systematic manner may represent a valuable source of knowledge for the rediscovery of forgotten remedies and the development of modern ethnopharmacology $[2,4,17,18]$.

While in some of the Eastern European countries, such as Poland [19-22], Estonia [12, 23, 24], Bosnia and Herzegovina [25, 26], and Russia [27, 28], the existing ethnobotanical resources are already thoroughly studied or actualized in several ethnobotanical surveys; a different situation exists in Romania. The content of the available Romanian ethnographic resources is still unknown by the rest of the world as they are not yet published (e.g., manuscripts found in various museums or libraries), or published only in the national language (e.g., "Botanica Poporana Romana" by Simion Florea Marian). These written resources cover mainly the period until de mid twentieth century.

Romania has a rich ethnomedical and ethnobotanical heritage. According to various antique texts authored by Dioscoride (Codex Constantinopolitanus, De Materia Medica) and Pseudo Apuleius (De Herbarum Virtutibus), many plants (e.g., Thymus vulgaris, Urtica dioica, Achillea millefolium, Mentha piperita) have been used as remedies on this territory since millennia, and are still used for similar therapeutic purposes in nowaday ethnomedical practices [29, 30]. Local historical documents mention the art of healing through herbs practiced by indigenous population beginning with the fourteenth century. Several manuscripts originating from various regions of the present day Romania or interwar Romania, dating from the fourteenth-seventeenth centuries, contain elements of medical botany. Some are kept in the Archives of the Library of Romanian Academy (e.g., manuscripts 740, 498, 573, 312) [8], others are found today outside Romania (e.g., the Slavonic manuscript from Hodros-Bodrog monastery, Banat, Romania, written in the fourteenth or fifteenth century, known as Hodoski sbornic or Miscelaneul de la Praga, is found now in Prague) [31]. The sixteenth century manuscript no.740 in the Romanian Academy Library is considered the oldest text of medical folklore presently existing in Romania. The initial section is entitled "The use of healing plants" and contains 12 pages 
with descriptions of indications of several medicinal plants (the section was longer, but some pages were lost) (e.g., small and great plantain, angelica, mint, burdock, gentian, etc.). In order to understand the cultural context of our country during the Middle Ages, it should be reminded that the territories of the present day Romania lie within the !!influence area of the Byzantino-Slavic culture; therefore, several of these manuscripts have mixed influences. For instance, despite the fact that manuscript no. 740 is written in Ukrainean Slavic language, it contains influences from Western and Central Europe (probably Dioscoride's Materia Medica or Matthiolus's commentaries to Dioscoride's work), as well as elements of local medical folklore [32].

More systematic documentation of local traditions of plant use in Romania, based on field studies, began in the nineteenth century, with the work of various ethnographers. Simion Florea Marian (1847-1907) initiated this type of work, and he was followed by Nicolae Leon (1862-1931), Charles Laugier (1875-1930), Alexandru Borza (1887-1971), George Bujorean (1893-1971), Valer Butura (1910-1989), and others.

The Romanian ethnopharmacological knowledge and practices were kept alive through oral tradition, within families of healers, midwives, medicinal plant collectors, and monastic communities in a form almost institutionalized until the XXth century $[11,30]$.

The ethnomedical Romanian practices are also attested by the lexical background. The manuscript Dictiones latinae cum valachica interpretatione by Teodor Corbea, the first encyclopedic lexicographic work created in the Romanian space, dating around 1701 and published only recently [33], contains approximately 400 names of plants, including medicinal plants [34]. In 1783, the calvinist priest József Benkő (1740-1814) from Transylvania, published the botanical dictionary "Nomina vegetabilium," which contains 429 species with 612 popular Romanian plants names, some also from the area of !! Muntenia [35]. In other important botanical work, Transsilvania Generalis, József Benkő stated that "the Romanian women use efficiently weeds neglected by others, to cure various diseases" [35].

Despite this valuable biocultural heritage, only a few local teams of researchers focused their attention on Romanian ethnopharmacological practices in the last decades [36-41]. The data collected by Romanian scientists in field studies after 1970s have been reflected in only a few reliable scientific publications [38, 39, 41]. We have also noticed a recently increasing international interest in traditional uses of medicinal plants on Romanian territory, especially by ethnic minorities [42-48].

Concerning the European ethnopediatry research, there is a relative scarcity of studies. Moreover, the majority of the available European ethnopharmacological field studies only contain isolated references to the medicinal plant use in children diseases, as they are not exclusively focused on traditional ethnopediatry, but rather on adult ethnomedicine. There are such isolated mentions on the traditional indications of medicinal plants in children in various European countries, in cases of digestive diseases [26, 49-59], bedwetting [25], respiratory diseases [55, 60-64], insomnia [52, 63], and growth delay [46, 65]. Nevertheless, more and more scientists try to gather and systematize the available world clinical data on the safety and efficacy of various herbal medicines in children [66-71].

\section{Romania-a country with rich biodiversity}

Romanian flora has unique diversity, being recently estimated to 3700 species of higher plants [72], including 57 endemic and 171 subendemic species [73]. One of the explanations of this biodiversity lies in the fact that Romania is a biological confluence point, located equally distant from both the North Pole and the Equator and from the Atlantic Ocean and the Ural Mountains. Thus, Romania is the most biogeographically diverse country of the European Union, possessing five of the ten officially recognized geographic regions: alpine, continental, pannonic, pontic, steppic. Moreover, no other European Union country possesses steppe region [72]. Its flora consists of Western and Central European, as well as Mediterranean spontaneous vegetal species, representing more than half of the European flora [30]. More than 700 species were identified as being traditional medicinal plants $[74,75]$. A recent evaluation concluded that there are 756 spontaneous medicinal plants in Romania, out of which 126 species are on the Red List, and 122 species are completely forbidden to be collected [76]. Suggestive for the ethnobotanical potential of Romania, is the fact that Romania is on the list of the most important European source regions of medicinal plants collected today from the wild, following behind other Southeastern European countries, such as Bulgaria and Albania [77].

Despite the richness of this biocultural heritage, the studies focused on ethnopediatrics in Romania, as well as in the rest of Europe, are absent. Therefore, we considered that filling this gap represents a priority for scientists. In order to spur the use of Romanian (and European) medicinal plants for the treatment of children diseases, we need first to review the historical use of plants in ethnopediatrics.

The main objective of the present review was to identify, collect, systematize, and prioritize the available bibliographical data related to the medicinal plants traditionally used to treat various pediatric diseases in Romania during the 1860s-1970s. 


\section{Materials and methods}

We have obtained ethnobotanical information by manual systematic search in various resources which are not covered in the main electronic databases, such as journal papers, reports, books and $\mathrm{PhD}$ works written in Romanian language. All of them, excepting one [11], are available in the Romanian Academy Library (https://bib lacad.ro//eng_index.html) and/or in the Romanian National Library (http://www.bibnat.ro/). Depending on the methodology used by the authors of these publications, the resources could be classified into four categories: (A) original publications (based on field study-type methodology) [9-11, 78-84]. Inclusion criterion was that the field work and observations had been performed before 1980, even if some of these studies where published after that date $[85,86]$ (or the studies included informants who were old enough, at the date of the fieldwork, to report plant use during the target period 1860s-1970s [10, 11, 87]); (B) review publications (based on documentation and synthesis of previous ethnographic or ethnobotanical works) [75]; (C) mixed publications (compilation of original field study and review of literature) [74, 85, 86]; (D) other types of document papers which report use of medicinal plants in children by Romanian people during the $1860 \mathrm{~s}-1970$ s period [88].

Table 1 contains a brief critical overview of all resources used in this paper. In the following paragraphs, details are provided regarding the seven most representative sources, ordered chronologically according to the date ethnobotanical data were collected or published [whenever the collection date was not available or not applicable (e.g., review work)]:

1. "Botanica Poporană Română” (engl. Romanian Folk Botany) by Simion Florea Marian (1847-1907), a Romanian folklorist, ethnographer, hystorian, and naturalist, active member of the Romanian Academy, one of the greatest collectors of information and writers on the Romanian legacy of medicinal plants. Although he was a priest and for the most of his life a schoolteacher, he is the one who layed the foundations of scientific folklore research in Romania. "Botanica Poporană Română" represents a monumental work of therapeutical indications and folklore on medicinal plants in Romanian territory, collected by the author himself from hundreds of informants (whose names and residing villages are mentioned in the book), during 1867-1907. His correspondence attested the fact that he collaborated with specialists from the Botanical Institute in Bucharest to identify (i.e., correctly establish the scientific names of) the plant voucher specimens in his herbarium. Unfortunately, his work was published only recently, one century after his death-this sorrowfully delayed publication was due to the huge efforts of an enthusiastic Romanian ethnographer, Aura Brădățan [85, 86]. This masterpiece was awarded a distinction by Romanian Science Academy, being considered a treasure of national culture.

2. Istoria naturală medicală a poporului român" (engl. Natural medical history of Romanian people) by Nicolae Leon (1862-1931), a Romanian biologist, professor at the Faculty of Medicine, Alexandru Ioan Cuza University, Iasi, published in 1903, in Romanian Academy Annals [84]. He had a very rigurous approach in his fieldwork, in terms of criteria used for plants inclusion in his study. He stated in the Foreword of the publication: "I have not mentioned the vegetal remedies quoted by some authors if I had not the possibility to make sure that the people use them indeed.(...)even if they were counted by Czihak and Szabo as folk medicinal plants(...) Even if they were counted by Czihak and Szabo as folk medicinal plants, the plants that I could not identify because of the lack of voucher specimens are all gathered in Notes, at the end of the Chapter I, and only their use is indicating, without the scientific name." The publication contains a special chapter entitled "Numiri vulgare cu cari poporul cunoşte bolele" (engl. Folk names by which people know the diseases), where the author offers the clinical picture of the diseases treated by Romanian folk medicine and also provides the scientific medical terms corresponding to a series of folk terms.

3. "Monografia comunei Răşinariu" (engl. Monography of Răşinariu village), by Victor Păcală (1874-1955) [9], awarded a distinction by Romanian Academy in 1916, is considered the best monography of a Romanian village written before the First World War [89], and represents even today a model for how a comprehensive descriptive ethnographic monography should be written.

4. "Contribuțiuni la etnografia medicală a Olteniei" (engl. Contribution to the medical ethnography of Oltenia) [82], by Charles Laugier (1875-1930) was granted Botez Prize by Romanian Academy in 1927. Charles Laugier was a physician who graduated from Carol Davila Faculty of Medicine in Bucharest in 1898. Latter he became Director and Sanitary Inspector for Oltenia region. During his regular inspections, he collected a lot of ethnographic information, including ethnobotanical and ethnomedical data which is cited even today by specialists. Laugier offers at the end of his publication a list with correspondences between folk terms designating 


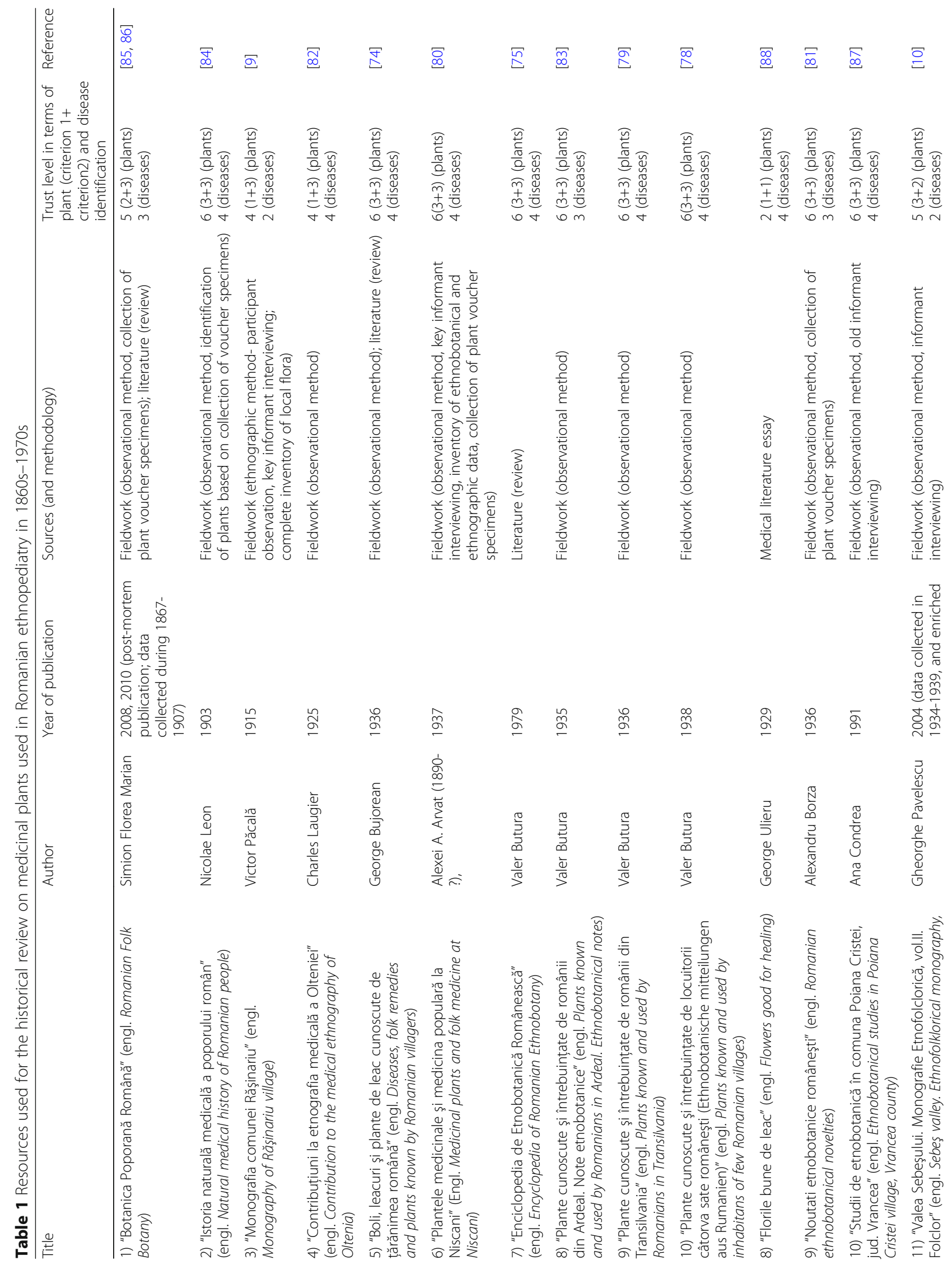




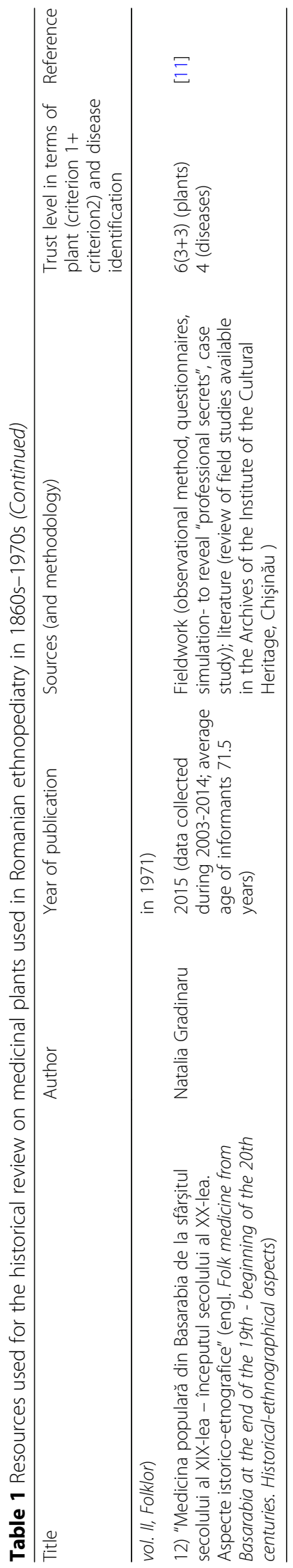


plants/diseases and scientific botanical/medical terms.

5. "Boli, leacuri şi plante de leac cunoscute de țărănimea română" (engl. Diseases, folk remedies and plants known by Romanian villagers) published in 1936 by another important figure in Romanian ethnobotany, George Bujorean (1893-1971), botanist and founder of Romanian experimental ecology and geobiology [74]. This publication became a national reference work for its period. Bujorean discovered several new plants with medicinal properties, which were used in Romanian folk medicine, but were not mentioned in Dragendorff's publication, which was recognized at that time as the world's ethnopharmacological reference list of medicinal plants [90] (e.g., Trifolium campestre L, Sempervivum marmoreum Griseb., known at that time by its synonym, Sempervivum assimile Schott).

6. "Plantele medicinale si medicina populara la Nişcani" (Engl. Medicinal plants and folk medicine at Nişcani) by Alexei A. Arvat (1890-?), a botanist well known in Romanian ethnographic world. He graduated Natural Sciences at Iassy University and published several valuable ethnobotanical works during his life. The one relevant for our present review is a comprehensive field study performed in the Nişcani village, Basarabia, during which he found 140 medicinal species traditionally used against 137 diseases. One of his conclusions is significant for the value of the local ethnobotanical knowledge: the number of medicinal species known to the population of Nişcani was close to the total number of species in that area, his informants claiming that "all the weeds have healing properties, only the people do not know" [80]. He also identified during this study new vernacular names for 41 Romanian medicinal plants. Another interesting conclusion of this work was that medicinal plants were used in folk medicine in Nişcani in a much higher proportion (85\%) than other remedies (e.g., incantations- descântece, organic or inorganic substances, etc.).

7. "Enciclopedia de Etnobotanică Românească" (engl. Encyclopedia of Romanian Ethnobotany) by Valeriu Butura (1910-1989) is a remarkable synthesis work which reveals more than 100 years of traditional Romanian medicine practice [75]. He was a botanist, student of another great Romanian ethnographer Alexandru Borza (1887-1971). Valer Butura started his ethnobotanical studies in 1930$1940[78,79,83]$. His encyclopedia containing more than 700 medicinal plants with traditional uses was published in 1979, 10 years after his professor published another reference work Ethnobotanical dictionary (containing 2095 species with over 11000 Romanian names of plants) in 1968 [91].

We estimated for each source used the trust level in terms of plant identification, using two graded criteria, as follows:

Criterion 1 (author's background): 3-author was botanist, biologist, or anthopologist; 2-the author was not a botanist, biologist, or anthropologist, but collaborated with botanists for the identification of plants; 1 -author was a physician or self-educated in terms of botanical and anthropological studies; 0-author was none of the previous.

Criterion 2 (plant identification): 3-if the author was able to differentiate between medicinal plants with claimed clear botanical identity and plants with unresolved botanical identity, and all the plants with claimed clear botanical identity had Latin names which were either accepted names or synonyms of the accepted names in The Euro+Med PlantBase (http://ww2.bgbm.org/ EuroPlusMed) [92] and/or The Plant List (www.the plantlist.org) [93]; 2-if the Latin names of the majority of medicinal plants claimed to have a clear botanical identity were either accepted names or synonyms of the accepted names in The Euro+Med PlantBase (http:// ww2.bgbm.org/EuroPlusMed) [92] and/or The Plant List (www.theplantlist.org )[93]; 1-if the Latin names of the medicinal plants were available for a small percentage of taxa, or a significant number of plant had unresolved names in The Euro+Med PlantBase (http://ww2.bgbm. org/EuroPlusMed) [92] and/or The Plant List (www.the plantlist.org) [93], or Latin names were not available (and plant identification was based on the vernacular name).

The sum of grades for the two criteria represented the trust level in terms of plant identification. The highest possible grade was $6(3+3)$, and the lowest possible grade was $1(0+1)$.

Whatever the trust level of the source, we did not include plants with unclear botanical identity in our work.

We estimated for each source also the trust level in terms of disease identification, as follows: 4-in the source, the diseases are identified by their scientific names or by both their folk and scientific names; 3some diseases are identified by their scientific names, others only by their folk names; 2-diseases are identified only by their folk names, whose modern medical equivalents could be determined nonetheless by means of dictionaries or other resources [74, 84, 94]; 1-diseases are designated only by folk terms whose significance in modern medical terms could not be established with the help of dictionaries or other resources. The 
higher the grade, the higher the trust level. The highest possible grade was 4 , and the lowest possible grade was 1 .

A medicinal plant was included in our database if its traditional use was mentioned by at least one author.

Despite the fact that the majority of the dietary plants may be used for children, those species where pediatric indications were implicit (due to their dietary value) were excluded from our study, while only the species with explicit pediatric indications (mentioned in the ethnographic text as such) were included. For instance, plants like Urtica dioica, Malus domesticus, Vitis vinifera, Persica vulgaris, Petroselinum sativum, Raphanus sativum, etc. were excluded, despite their ethnopediatric potential. Beside the objective restrictions imposed by the limited availability of written resources, this approach was adopted in order to (1) reduce to zero/nullify the risk of selecting a wrong plant, (2) avoid overloading the paper with too many common plants with universal dietary value, and (3) identify local non-nutritional medicinal plants with pediatric indications, which might be less known to the scientific community.

Regarding the name of the plants-in our sources a perimated Latin term was sometimes used for species identification. In all these cases, the perimated Latin term was changed to the presently accepted one (e.g., Galium odoratum (L.) Scop. instead of Asperula odorata L.). More often than not, a given species had several vernacular names-in such cases, all the various vernacular names encountered in our sources were gathered as a unique entry under the accepted Latin name (e.g., "sânziene de pădure," "vinariță," and "mama pădurii" are put together under the accepted latin name Galium odoratum (L.) Scop.).

Data analysis and extraction were performed by medical professionals involved in clinical and scientific research at academic level. All data were cross examined by a second author.

Concerning the indigenous classification of diseases in Romanian traditional medicine, to the best of our knowledge, no systematic classification is provided by the available historical resources. In order to avoid suppressing the cultural traits, we have adapted the International Classification of Primary Care (ICPC) [95] to our set of data. ICPC was reported to be a closer approximation to ethnomedical reality and emic perspective, than other modern classifications such as International Statistical Classification of Diseases and Related Health Problems (ICD) or the Economic Botany Data Collection Standard (EBDCS) [96].

Preliminary data concerning traditional pediatric indications and the parts used were organized in a tabular form. Afterwards, we performed a second systematic search in PubMed for all the medicinal plants recorded for ethnopediatric use which were included in our database, in order to identify whether their therapeutic potential was evaluated or not in clinical pediatric studies.

\section{Data analysis}

We divided the collected bibliographic material into use categories such as various types of diseases, based on the International Classification of Primary Care (ICPC) (WHO | International Classification of Primary Care, Second edition (ICPC-2), 2012).

In order to compare the utility of medicinal plants in Romanian ethnopediatry, we proposed one index: Ethnopediatric Relative Therapeutic Versatility (ETRV).

In our analysis, all ethnopedriatic uses included under the umbrella of a certain targeted body system were counted as one. For each medicinal plant, we summed up all the targeted body systems and obtained a value designated as BS. Phylogenetically closely related medicinal plants (the single case of Populus spp.), which had similar ethnomedical uses, were counted together, as a single phytotherapic entity. The formula used for the calculation of ERTV expressed as percentage was:

$$
\mathrm{ERTV} \%=\frac{B S i}{B S \max } \times 100
$$

where $\mathrm{BS}_{\mathrm{i}}-$ number of body systems targeted by the plant $\mathrm{i} ; \mathrm{BS}_{\max }-$ maximum number of body systems targeted by a single plant obtained in our bibliographic study (which is seven). For example, Gratiola officinalis is traditionally used to treat six body systems, one less than 7, corresponding to Dryopteris filix-mas (L.) Schott, the most versatile of all species. Therefore, it has ERTV of $85.71 \%(6: 7 \times 100)$.

Altogether, more than 30 local publications were used for this historical review to collect information about medicinal plants used in Romania (1860s-1970s), but only in 15 publications we have found relevant data for ethnopediatrics. Since some of the publications rely on identical sources (e.g., George Bujorean [74] is cited by other ethnographers, such Valer Butura [75]), we considered that the number of citations did not express the relative importance of the species in Romanian ethnopediatrics.

\section{Results}

We have identified in the available literature several old Romanian terms comprising children-specific diseases (acrum-newborn aphthous stomatitis, babiți-digestive troubles in children caused by tooth eruption, boala cânească/socote/sohote/zilizit-athrepsia, severe nutritional disturbance in small children, boala copiilor/răul copiilor/răutatea copiilor/ceas rău/samca/sanca-convulsions, epilepsy, coriu/coriu adevărat/bubatu al mic- 
measles, coriu negru-scarlet fever, focușor-red papular eruptions on face or chest in children, lamoste-child dysentery, mătrice-cramps in newborns due to abdominal gas accumulation, muma pădurii-nightmares/insomnia/weeping during night in small children, oase moi ("soft bones")/oase strâmbe ("curved bones")—rickets, opăreală-diaper/napkin dermatitis, rahnă-cold, pleasnă/plesne-irritation of lingual and palatal mucosa or aphtous stomatitis, especially in small children, rodimcic-nervous spasms, convulsions, cramps in newborns, strâns-diarrhea of children, suldumaș or surdumaș-small red papular eruption on the newborn scalp, tuse măgărească-whooping cough) or disorders common in both adults and children (apucătură- colic, arâne/fudulie- scabies, boli lipicioase- contagious diseases, bubă- abscess/pustule/purulent subcutaneous collection, bube dulci/rofii/rohii-impetigo, cufureală/ treapăd-diarrhea, gîlci-tonsillitis, izdat/surdumaciabdominal pains, mărgăritărel-stomatitis, scrofuri-tuberculosis of the lymph nodes, trecătură-gastro-enteritis) $[74,75,85,94,97]$. Some of them are still used in the modern language (e.g., tuse măgărească, bube dulci, cufureală, gîlci).

After adaptation of the International Classification of Primary Care (ICPC) [95] to our set of data, we had 12 categories of body system-related pediatric diseases (Table 1).

A total of 153 medicinal plants belonging to 52 families were identified as having ethnopediatric relevance- they are presented in the alphabetical order of their Latin name in Table 3, which also includes the medical indications, targeted body systems, parts used, way of administration (where available), and ERTV. Half of the species (49.67\%) used in Romanian traditional medicine to treat children diseases belong to seven families: Asteraceae (21), Lamiaceae (15), Apiaceae (12), Rosaceae (ten), Fabaceae (seven), Ranunculaceae (six), Brassicaceae (five).

The plant indications, targeted body systems, parts used, way of administration (where available), ERTV, and available scientific evidence are provided in Table 2.

The distribution of the plants with respect to their medical indications is as follows: blood, lymph and spleen diseases (five species), cardiovascular (one), digestive (53), ear (two), endocrine, metabolic, and nutritional (28), general (45), musculoskeletal (11), neurological (22), psychological (26), respiratory (14), skin (44), urological diseases/conditions (one).

The top of the seven most versatile plants in Romanian ethnopediatry is represented in Fig. 1.

Only 15 medicinal plants were scientifically evaluated in pediatric clinical studies, or at least in human clinical studies with mixed groups of subjects (adults and children). For six plants, we found some positive evidence for few indications mentioned in Romanian ethnopediatrics; for ten medicinal plants, some positive evidence for certain indications not mentioned in Romanian ethnopediatrics, and for one plant some negative evidence.

Table 2 Classification of ethnopediatric indications in the present study, adapted after the International Classification of Primary Care (ICPC)

\begin{tabular}{ll}
\hline Category & Examples of diseases \\
\hline General and unspecified & Asthenia, Chicken pox/Varicella, Scarlet fever, Colic, Cramps, Fever, Measles/Rubeola, \\
Blood, blood forming organs, lymphatics and spleen & German measles/Rubella, Spasms, Tuberculosis, Weakness, Physical debility \\
Cardiovascular & Anemia, Enlarged lymph nodes, Scrophulosis \\
Digestive & Tachycardia \\
& Abdominal cramps, Abdominal pain, Acute digestive infections, Colitis, Constipation, \\
& Dental abscesses, Dental cavities, Dental eruption, Diarrhea, Digestive cramps, Dysentery, \\
& Enteritis, Flatulence, Intestinal cramps, Intestinal parasites, Intestinal worms, Stomatitis, \\
Ear & Tape worms, Teeth ache/pain, Ulcerative stomatitis, Vomiting \\
Musculoskeletal & Ear discharge, Ear pain \\
Neurological & Bone diseases, Bone deformities, Disability/Weakness of the extremities Rickets, Trauma \\
Psychological & Convulsions, Epilepsy, Paralysis \\
Respiratory & Agitation, Anxiety/Fright, Enuresis, Irritability, Sleep disturbances/Insomnia/ Nightmares/ \\
& weeping during sleep, Psychosis \\
Skin & Acute respiratory diseases, Asthma, Bronchitis, Phlegm in the throat, Cold, Cough, Cough \\
& with sputa and puss, Whooping cough, Respiratory infections, Tonsillitis \\
Endocrine, metabolic and nutritional & Acne, Burn wounds/Burns, Dermatitis, Diaper (napkin) dermatitis, Eczema, Hair complaint, \\
Skin inflammation, Skin infections, Impetigo, Scabies, Skin lesions, Subcutaneous tumors, \\
Verruca, Wounds
\end{tabular}




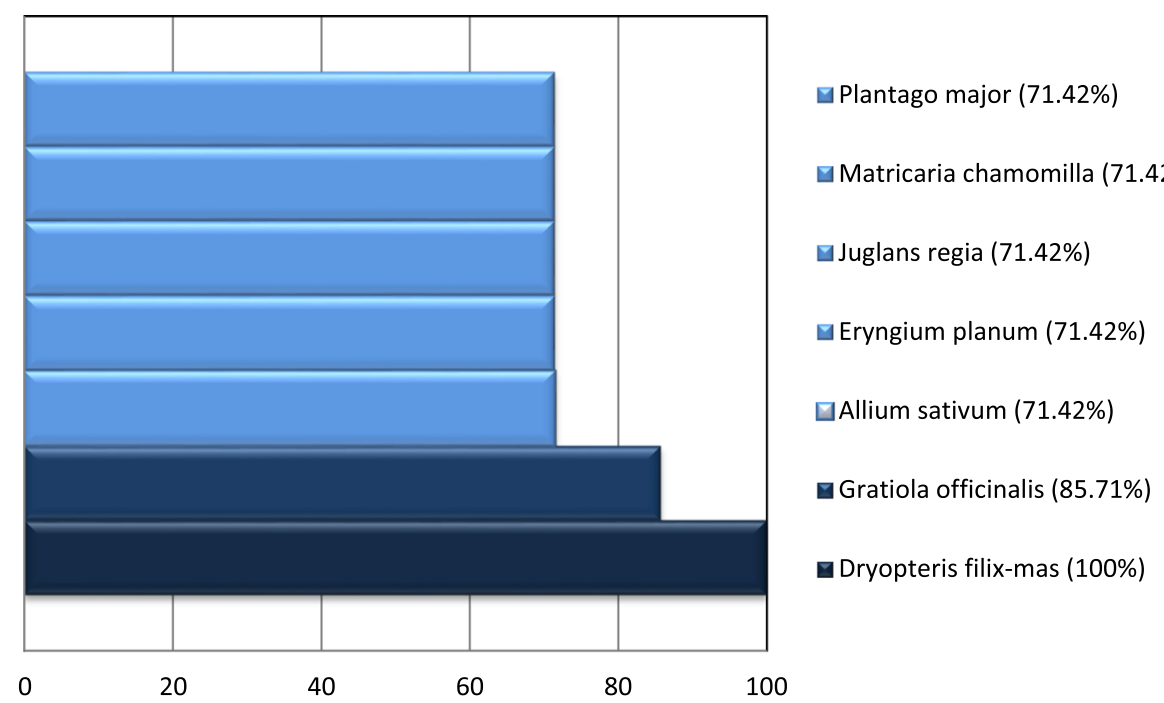

Fig. 1 Top 7 of the most versatile plants in Romanian ethnopediatry (Ethnopediatric Relative Therapeutic Versatility- ERTV- expressed as percentage)

\section{Discussion}

Ethnopediatrics in Europe, as well as in Romania, represents a neglected field of research. Many potential reasons could explain this fact. Regarding clinical trials (not only with herbal medicines, but also with synthetic drugs) in this vulnerable population, we should take into account, first of all, that The European Pediatric Regulation was adopted only recently, in 2006, and entered into force in 2007 [120]. Moreover, scientists face multiple challenges related to small subjects' population, economical burdens, pharmacological issues (extra-toxicity test required, higher risks of unpredictable severe adverse reactions in children than in adults), ethical concerns, necessity of additional parental consent, multiple age groups with specific needs and dramatic differences between them, difficulties in communication with children, high percentage $(60 \%)$ of children who do not assent to take part in research studies, high rate of withdrawal, etc. [121, 122]. Owing to all these constraints, it was suggested to use all available knowledge (e.g., clinical pharmacology data generated by using many therapeutic agents with no approved dosing labels and guidance), as well as modeling and simulation approaches in drug development [123]. We have proposed here a complementary solution to fill the actual gap in the pediatric research: to use all available, but neglected ethnopediatric knowledge, starting with systematic analysis of historical resources, and following with field studies. The present paper follows this direction, focusing on the review of medicinal plants used in Romanian ethnopediatrics in the 1860s-1970s.

More than 700 common species of medicinal plants are listed in various resources as being used in Romanian traditional medicine [74, 75, 124]. According to the present study, around one-fifth of them are highlighted as having ethnopediatric indications. We have also noticed that a great part of the indications of phytoremedies in children are for acute diseases: from a total of approximately 80 different types of illnesses, about two-thirds were acute (e.g., acute respiratory diseases, acute digestive disorders with vomiting and diarrhea, intestinal colic and other types of pains, spasms, wounds, chicken pox, scarlet fever, dental eruption, etc.) (see Table 1). This fact is expected since children often have acute, short-term illnesses [125]. Also, some of the most common adult diseases that are chronic (e.g., cardiovascular, central nervous system and oncological diseases) are less frequent in children [126].

Some of these plants have been cultivated and have been part of everyday Romanian diet for many centuries: aromatic plants (e.g., Foeniculum vulgare, Mentha piperita, Levisticum officinale), fruits and seeds (e.g., Pyrus communis, Rosa canina, Juglans regia, Cucurbita pepo), vegetables (e.g., Zea mays, Phaseolus vulgaris, Vicia faba, etc.), various recipes being preserved during the centuries, especially in the rural communities [30, 127]. Some particular Romanian plant-based dishes, which are also consumed by children, are pumpkin pie (from Muntenia area), bean soup (from Transylvania), home-made noodles ("iofca") prepared with cabbage, nuts, poppy (from Banat) [127]. Interestingly, the experts in food sciences suggested that the traditional cooking methods and habits seem to selectively preserve the specific benefic activities of different phytochemicals [128, 129]; therefore, we suggest that studying the traditional recipes may inspire new extraction methods of bioactive constituents. 
Concerning the fact that only some of the plants were specifically marked for use in children in the studied book and papers, a question arises: what is the reason or reasons behind this specification? We can only hypothesize. Potential explanations are the following: these plants might have been more frequently used or considered to be more efficient in their therapeutic activity by the informants or ethnographers, the informant might had a special direct experience with that plant, a certain plant or plant use might had a special value for a local community or for a family of healers, transmitted information might have been uncomplete due to weak memory of the informant. It was also suggested that the traditional ethnopharmacological knowledge is unevenly distributed (e.g., women, as managers of household health and mothers, might know more about ethnopediatric remedies than men; differential acces to the landscapes, such as forests, and therefore to certain medicinal plants; increased amount of knowledge with age of informant, etc.) [130-133].

\section{Ways of medicinal plant administration in ethnopediatry in Romania}

In Romanian ethnopediatry, medicinal plants are prepared in various ways, which are intended for internal use (infusions, decoctions, syrups), external use (baths, ointments, cataplasms, fumigations, inhalations), or both (infusions, decoctions). Alcoholic preparations are in general not recommended in Romanian (ethno)pediatry [85]. The reason is obvious, since alcohol is known to be toxic when administered to children $[134,135]$. WHO proposed the limitation in the ethanol content of pediatric products to less than $0.5 \%$ [136]. We noticed that the most frequently cited way of administration for small children in Romanian ethnopediatry was by bath, not only for skin diseases, but also for internal diseases, such as digestive or neurological ones, due to the fact that the quantities of phytochemicals absorbed through the skin, albeit small, are sufficient to be active in young children, particularly because phytochemicals can reach the bloodstream easier through the skin in small children than by internal administration in adults [137-139].

\section{Use of toxic plants in Romanian ethnopediatry}

In our bibliographic study, we have noticed that in Romanian ethnopediatry some of the toxic alkaloid-rich species (Aconitum napellus, Dryopteris filix-mas, and Tanacetum vulgare) have been traditionally prescribed under rigorous dosing, with the specification of increased toxicity $[75,86,124]$, some of them even for internal use (e.g., Acontium napellus for epilepsy, Dryopteris filix-mas for scrophulosis)! We have noticed in some of these cases that the traditional recipe is usually a polyherbal multimineral formula, with a complicated way of preparation. The rationale behind this may be the reduction of plant/mineral toxicity, similarly to the herbo-mineral ayurvedic preparations called rasa oushadies [140]. We give one such example from Romanian ethnomedicine. In Bucovina, the peasants used to prepare a decoction of wolfsbane (Aconitus napellus L.) and silver thistle (Carlina acaulis L.), over which they added sineala (syn. ultramarine), a blue mineral dyestuff used in the past to bleach the laundry, obtained by melting a mixture of kaolin, sodium carbonate, wood ash, and sulfur. This complex liquid preparation was administered to the child suffering from epilepsy (Rom. raul copiilor), both internally (a very small amount) and externally (as a whole body washing) [86].

\section{Comparison of relative therapeutic versatility of top medicinal plants in Romanian ethnopediatry}

Concerning the ERTV index, we discovered several interesting facts. Surprisingly, the versatility hierarchy is topped by two less commonly used medicinal plants with toxic potential: fern (Dryopteris filix-mas) with ERTV $100 \%$ and gratiole (Gratiola officinalis) with ERTV $85.71 \%$. Not unexpectedly, next to these two species were four common medicinal species, used in many parts of the globe in ethnopediatry [garlic (Allium sativum), nut tree (Juglans regia), chamomile (Matricaria chamomilla), and broadleaf plantain (Plantago major)], and another one less known for its ethnopediatric use, blue eryngo (Eryngium planum), all having equal scores (ERTV 71.42\%). Dryopteris filix-mas' biological activities are not yet scientifically studied, except for its antiinflammatory potential (one animal study) [141]. Gratiola officinalis' therapeutic activity is more evidence based; its anti-inflammatory (correlated with its ethnopediatric use in eczema, see Table 3) and sedative (correlated with its ethnopediatric indication in fright during sleep, see Table 3) potential being partially supported by animal or in vitro studies [142, 143]. Nevertheless, its ethnopediatric use in physical debility, epilepsy, paralysis, and tachycardia has no scientific support yet.

Garlic (Allium sativum) (ERTV 71.42\%) was used for centuries in different cultures for the treatment of many diseases and is also one of the best studied herbal remedies [144]. Several recent studies raised the possibility of revival of some of its ethnopharmacological uses (mentioned also in Romanian folk medicine), which may be beneficial in child infections $[99,100]$, respiratory diseases [101]. In vitro experiments revealed some further therapeutic properties (benefits in alopecia areata [102], anticancer activity [145]).

Walnut tree (Juglans regia, Juglandaceae) (ERTV $71.42 \%$ ) is a tree known to humankind since prehistoric times, its fruits representing an important source of 


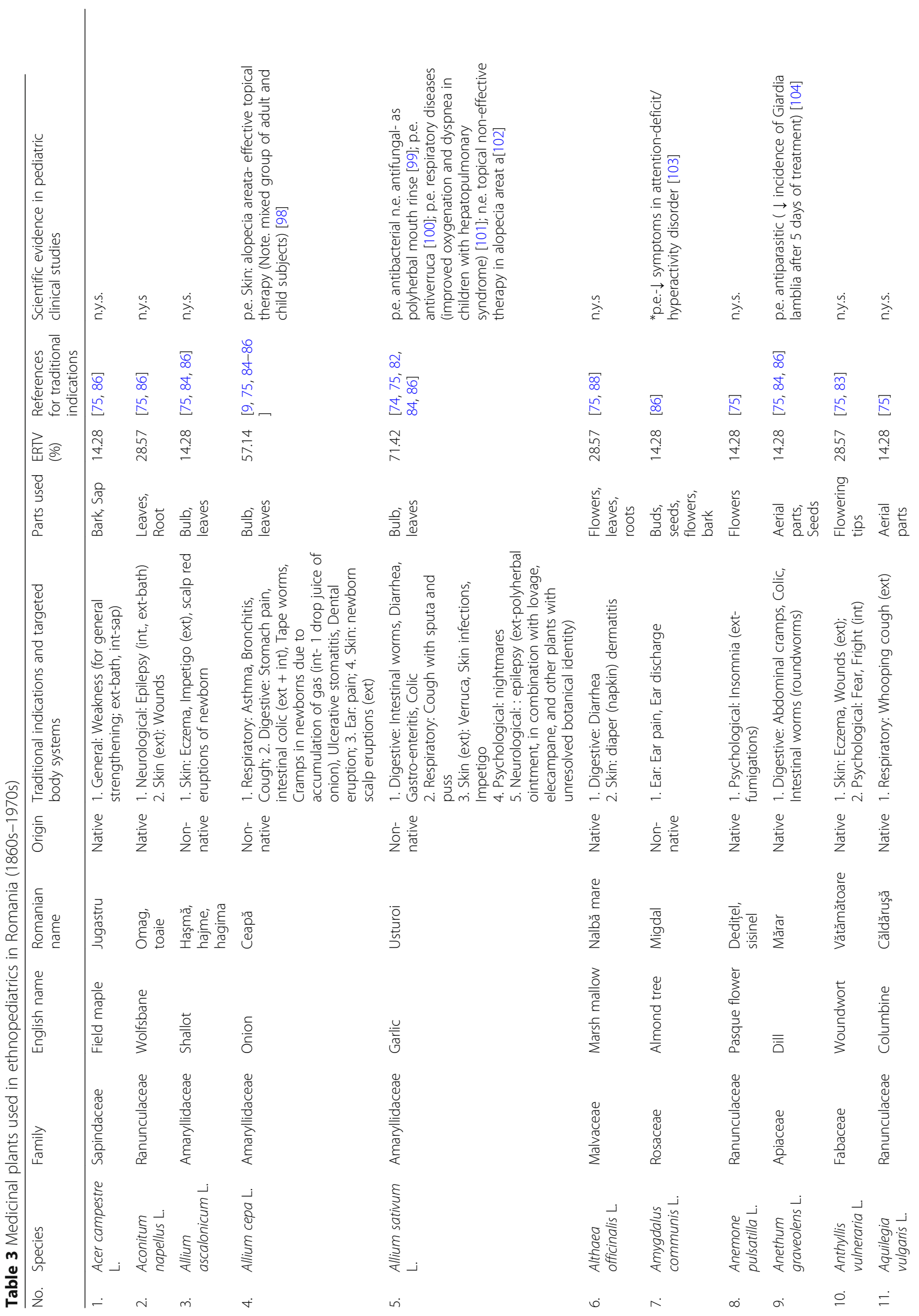




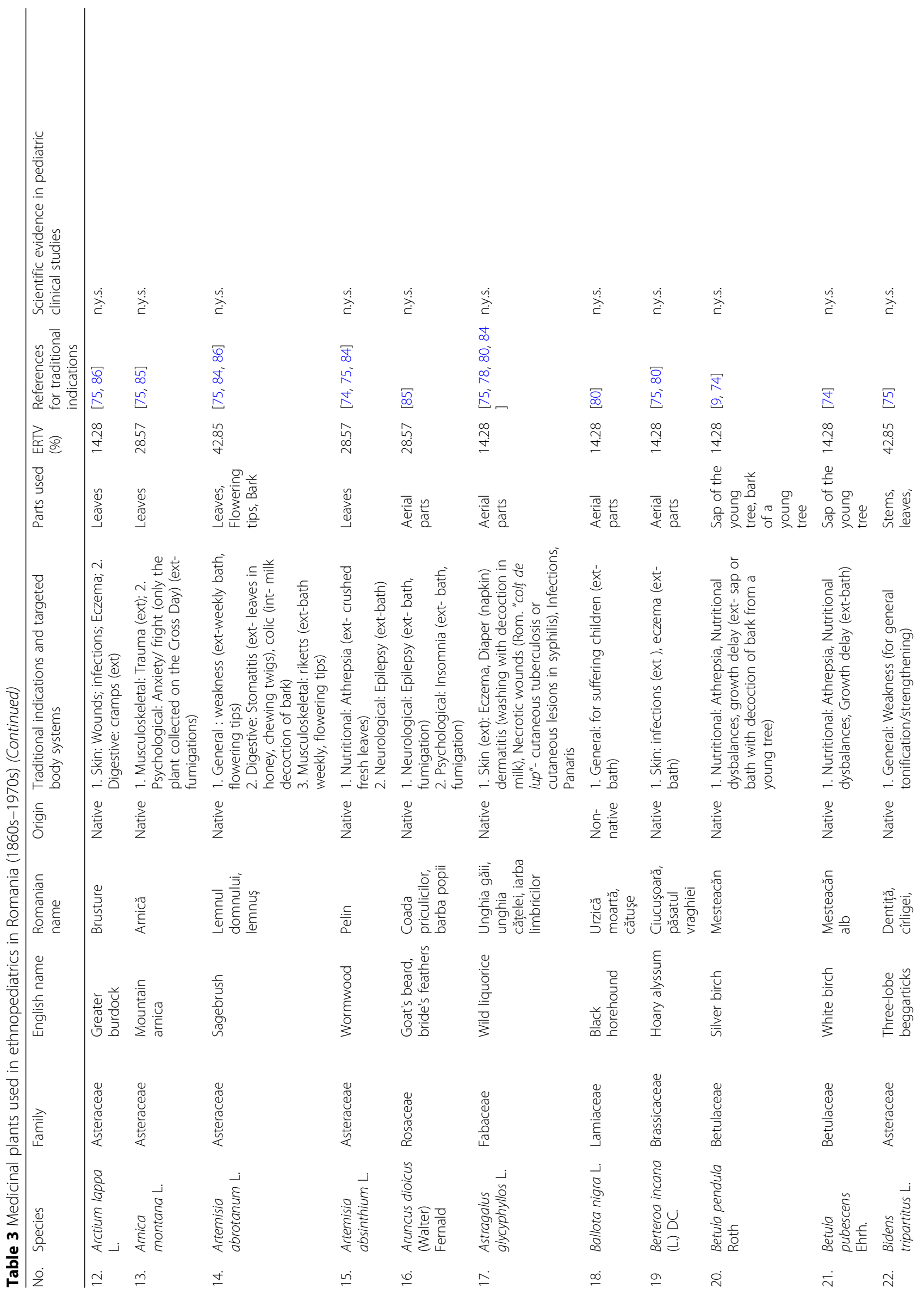




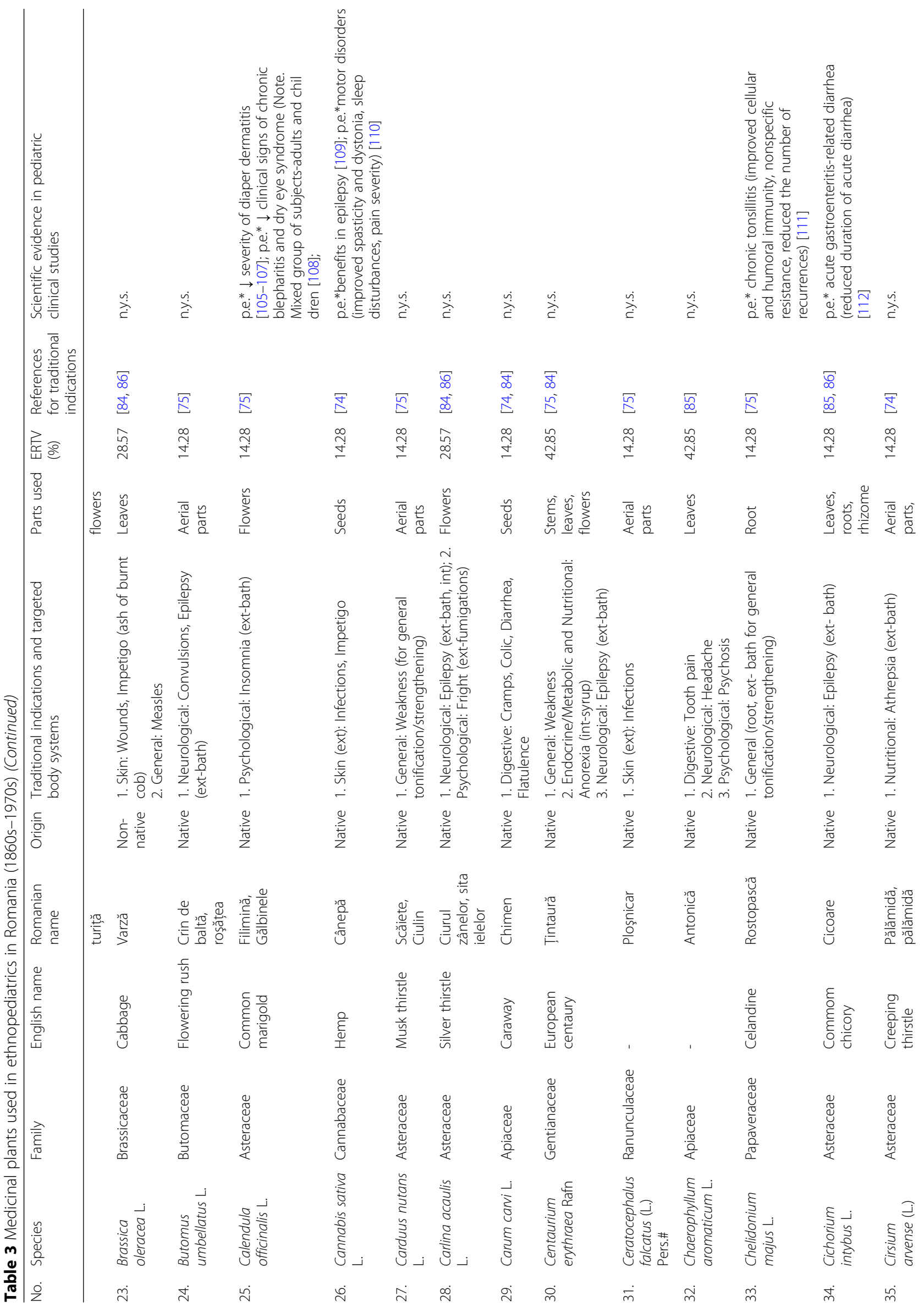




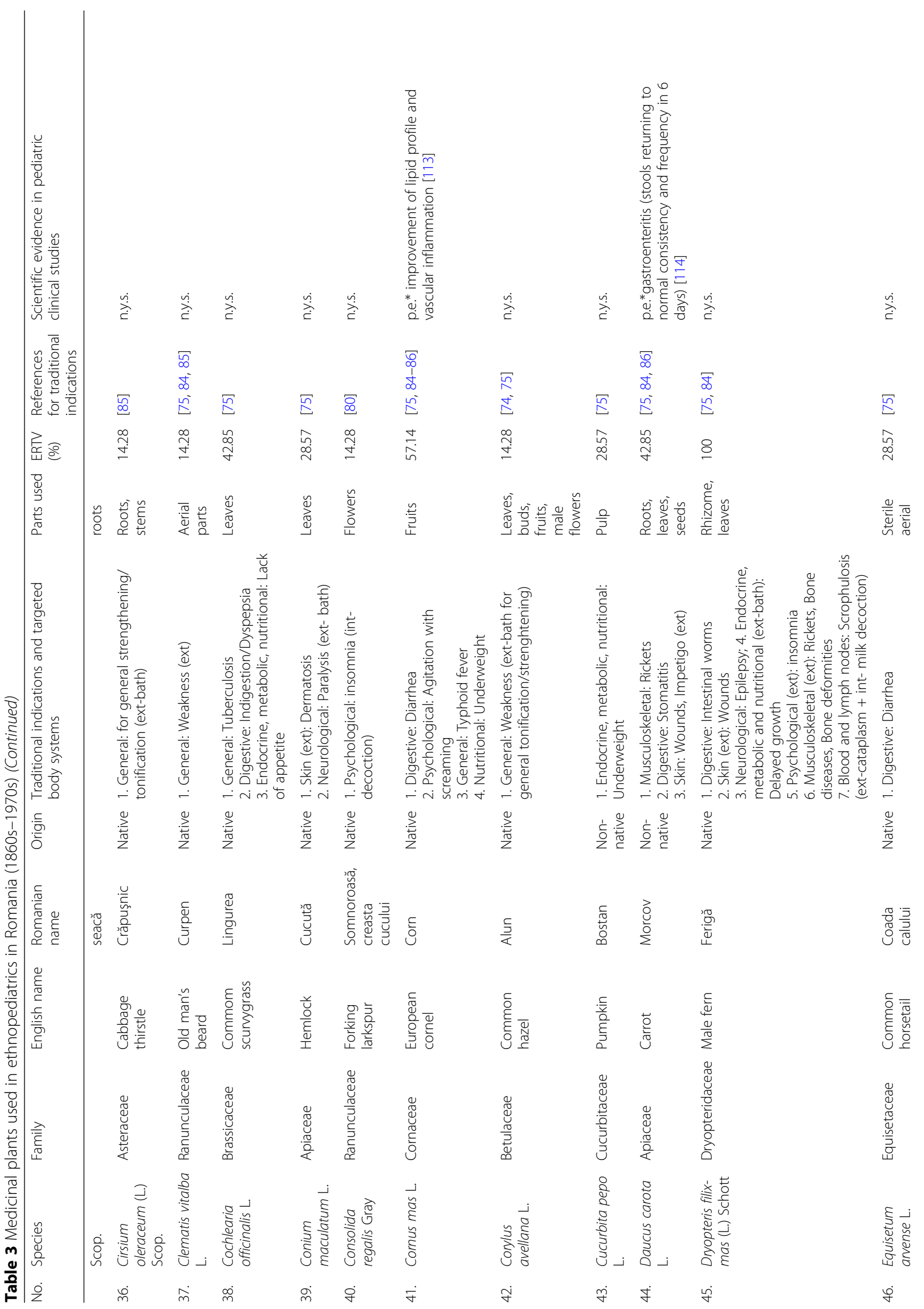




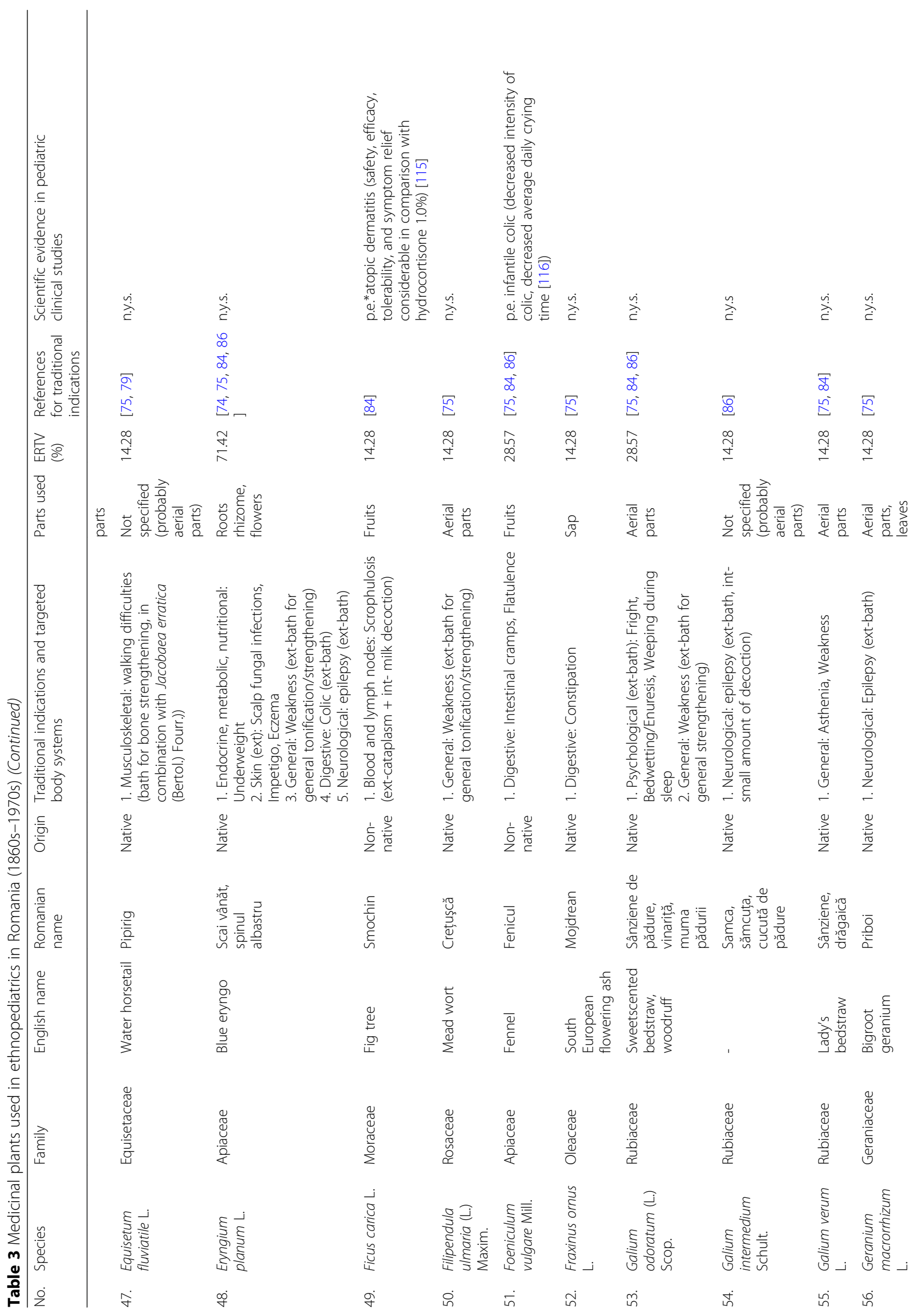




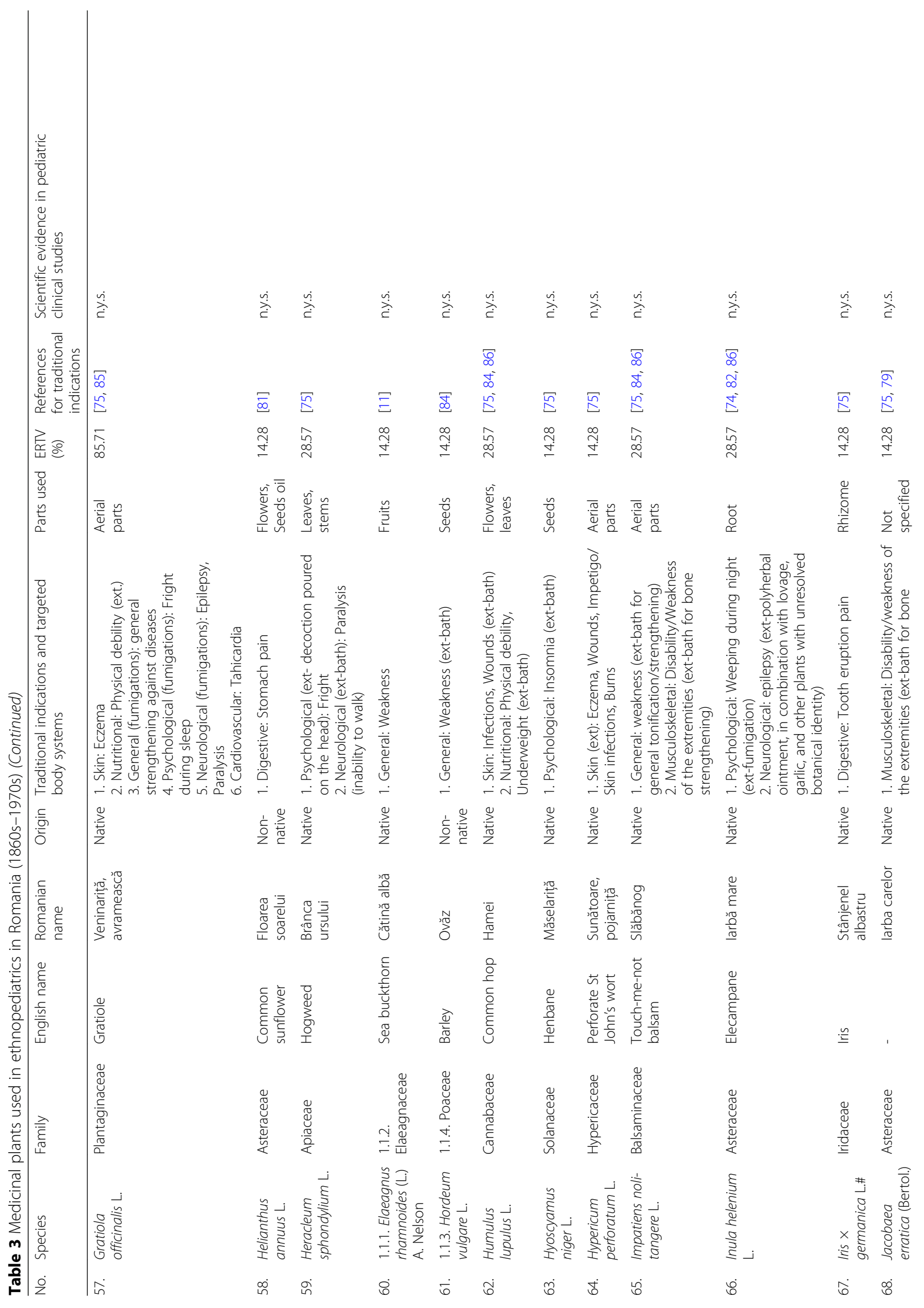




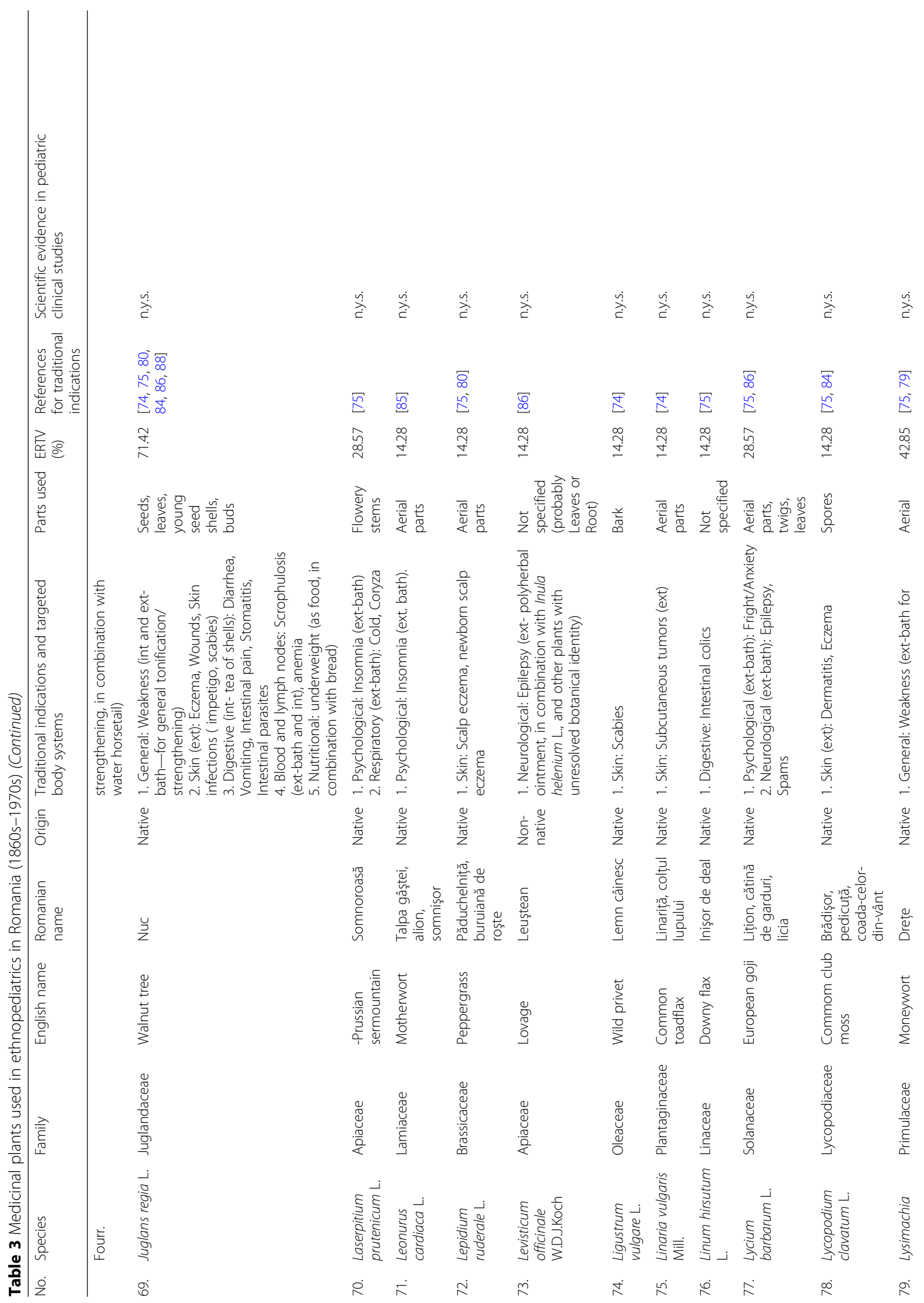


Petran et al. Journal of Ethnobiology and Ethnomedicine

(2020) $16: 15$

Page 19 of 33

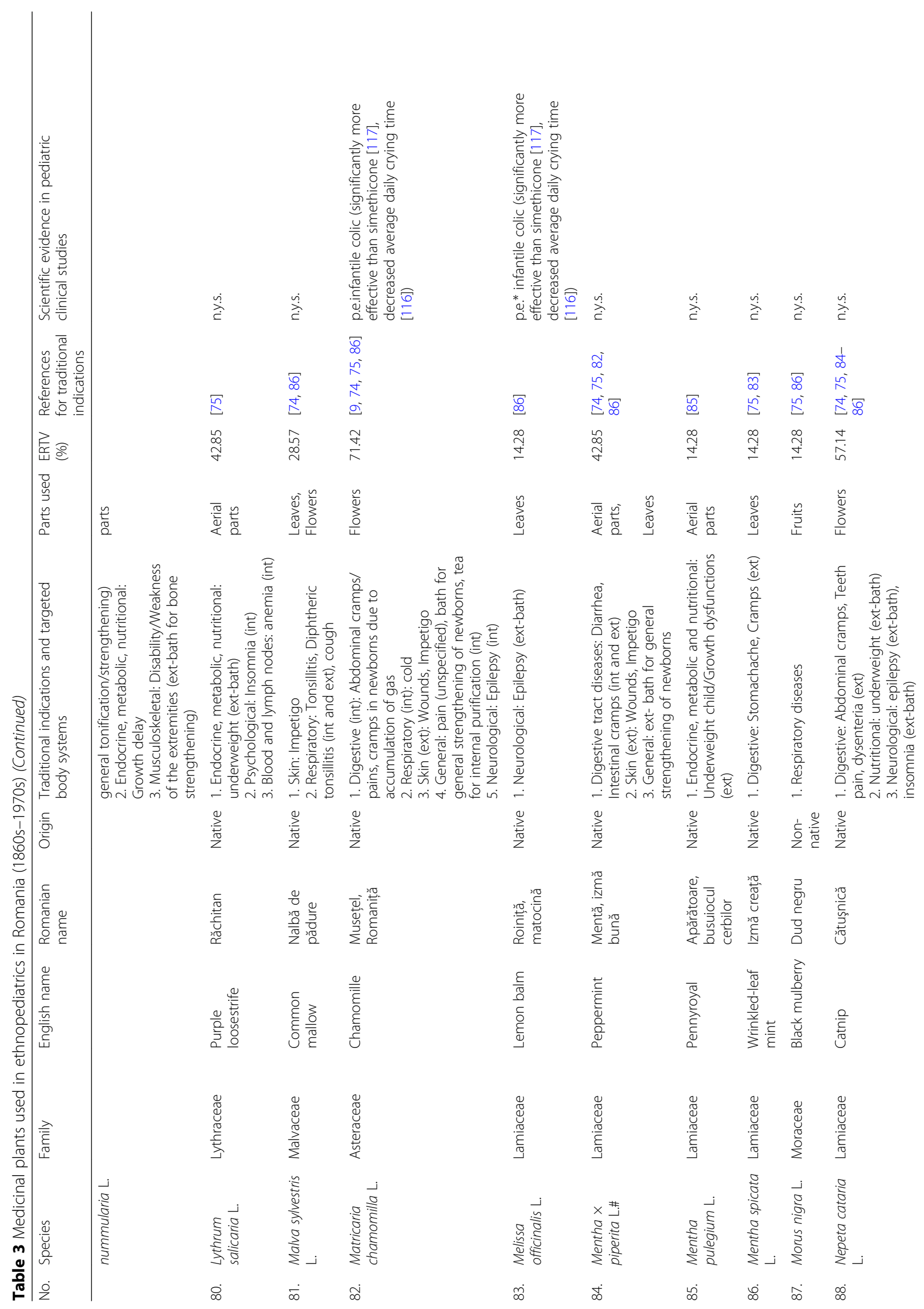




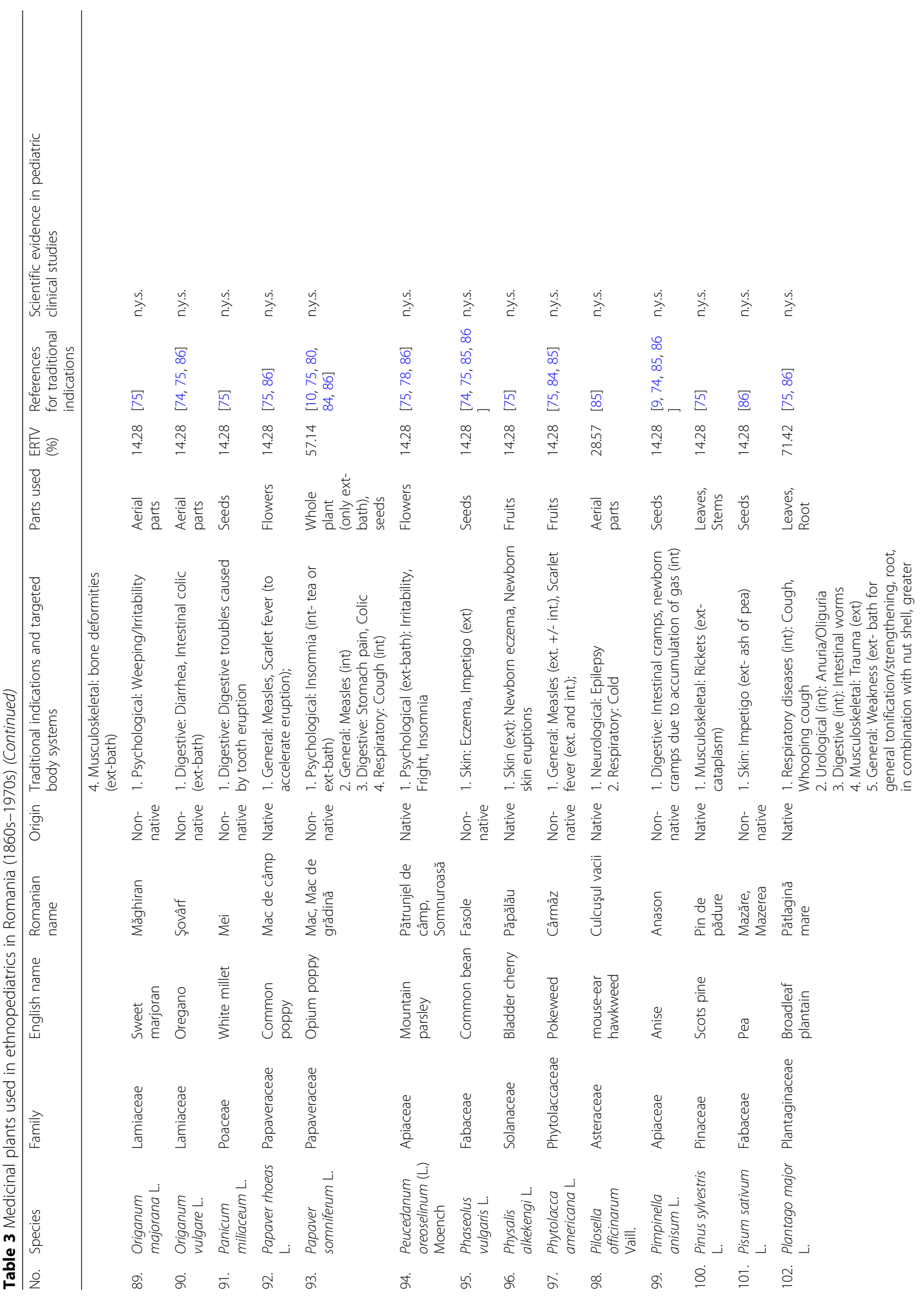




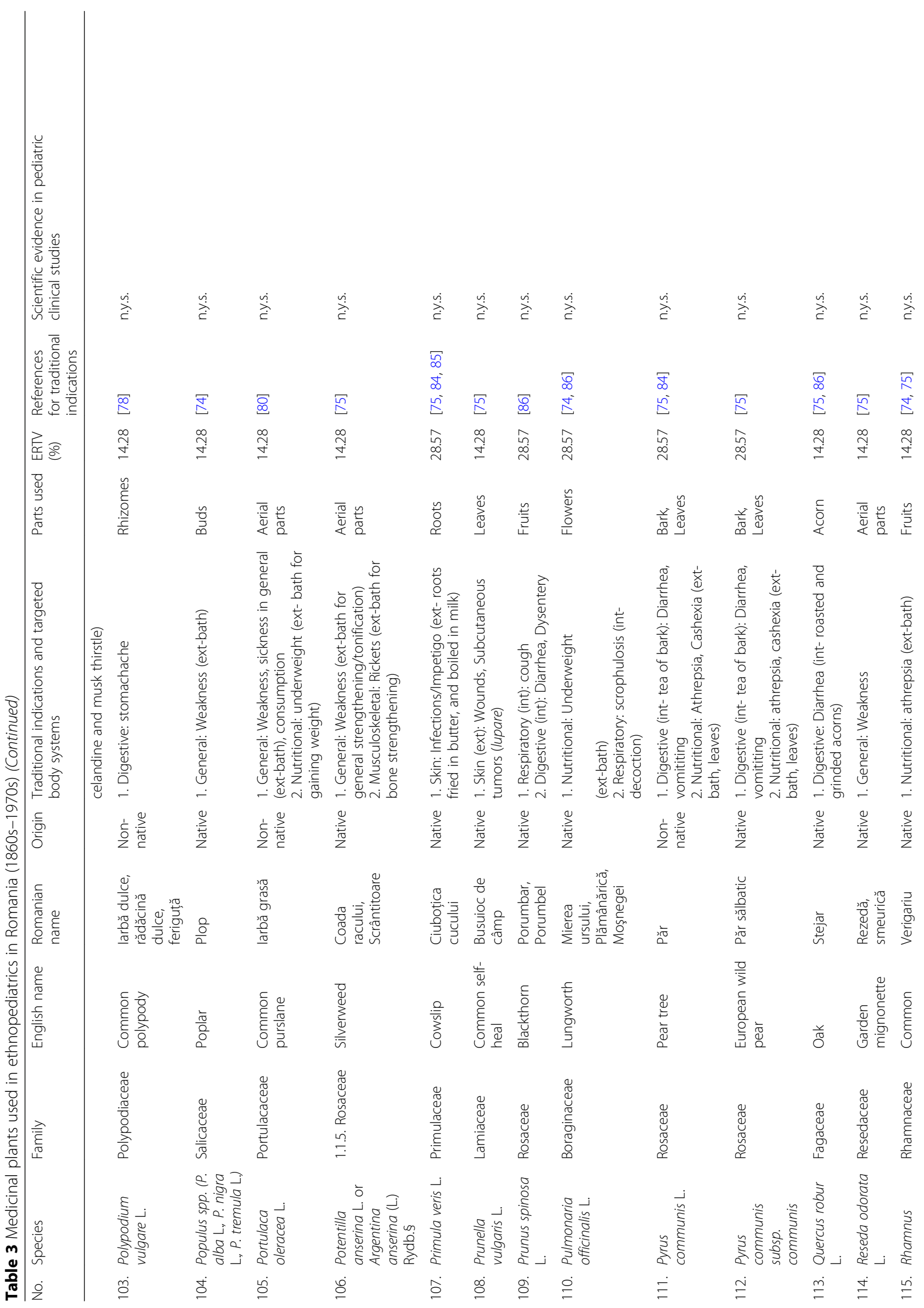




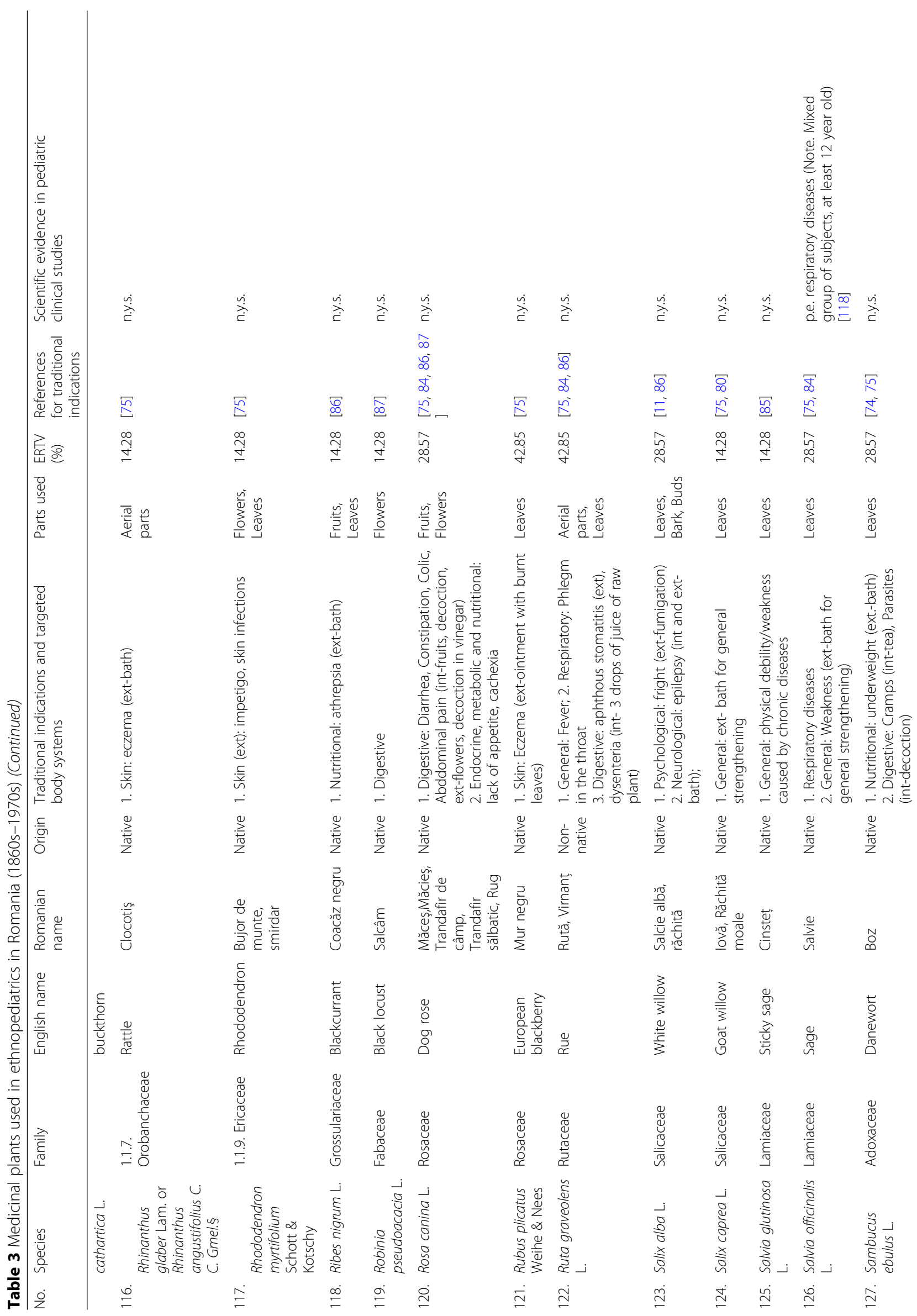




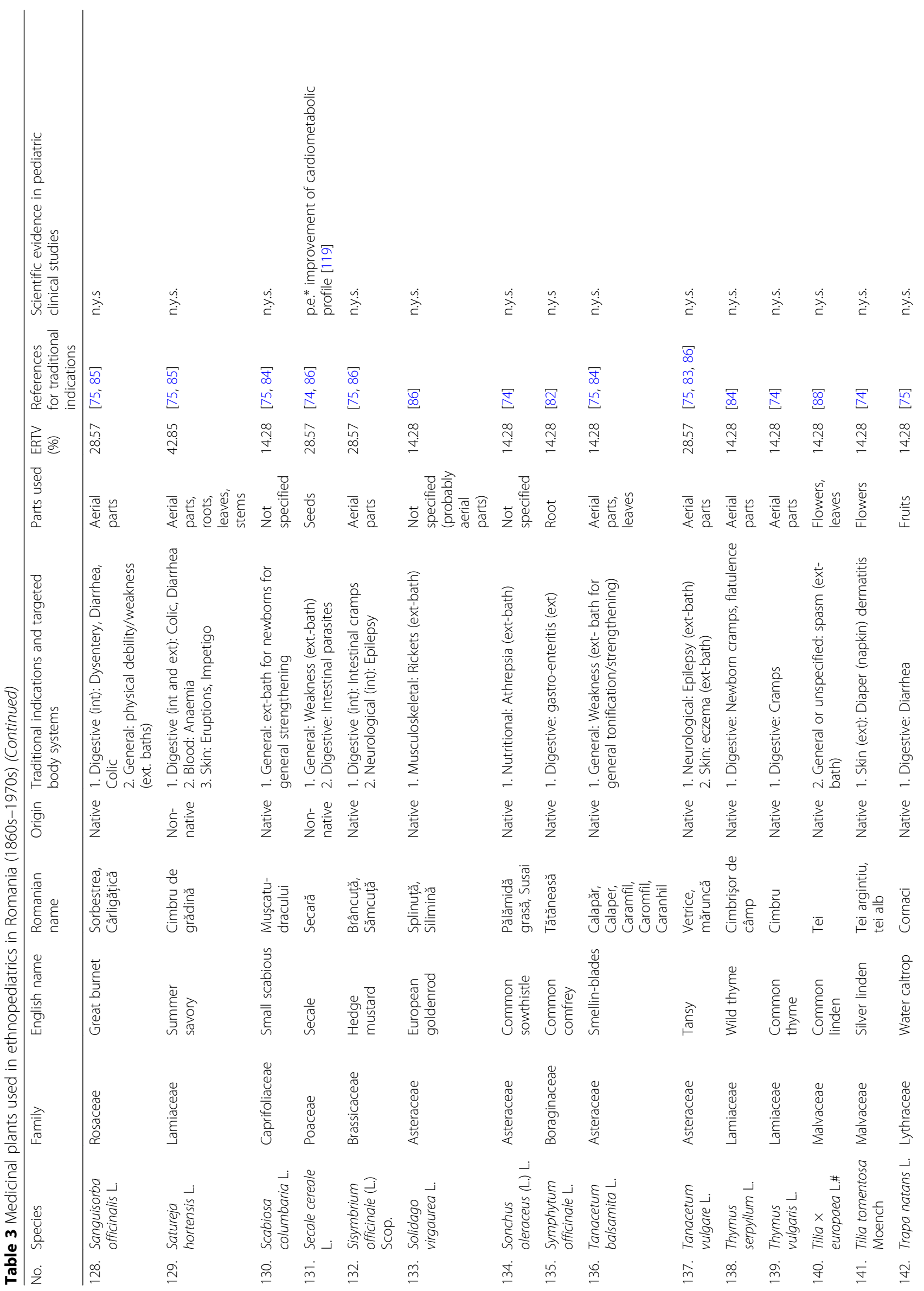




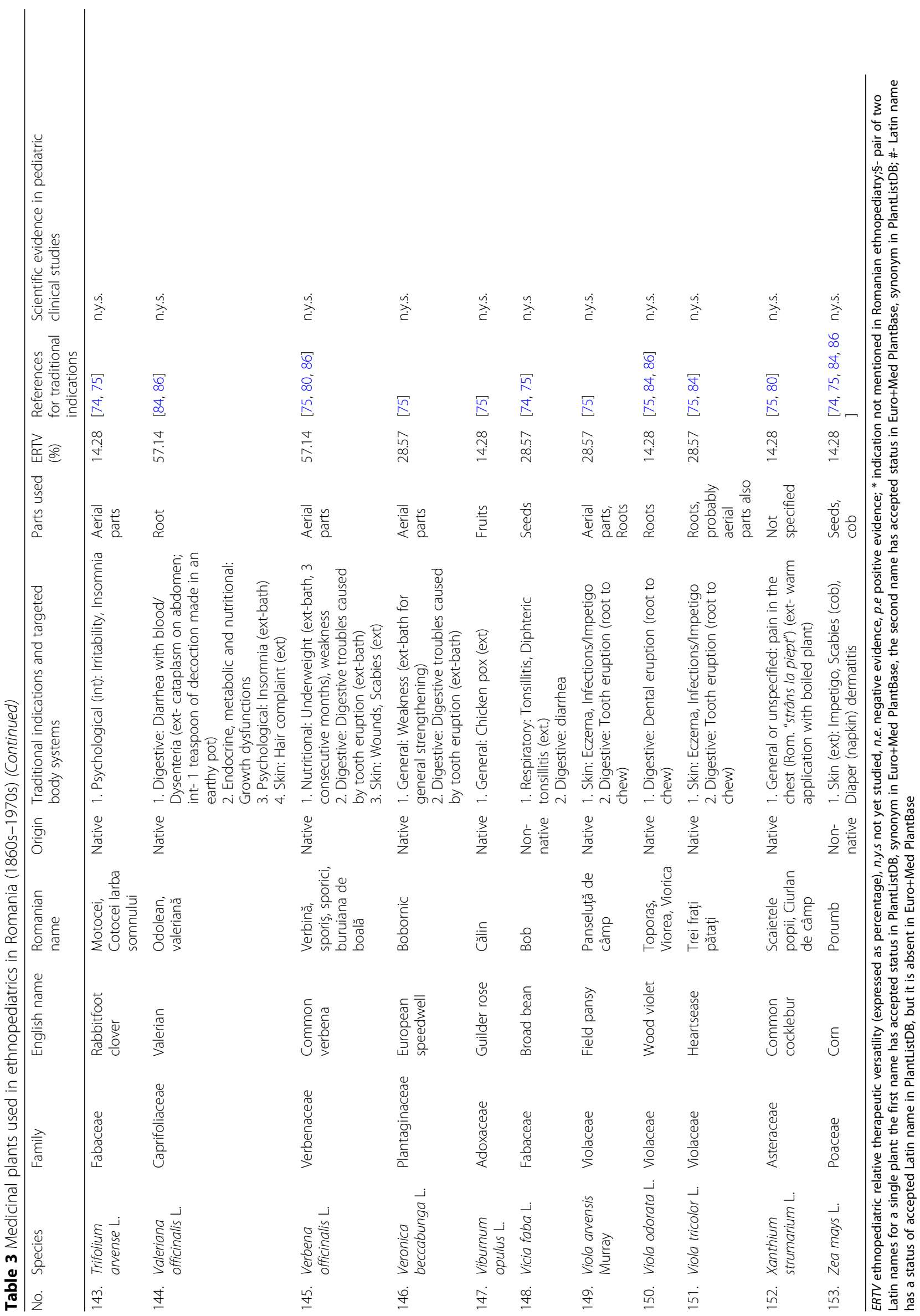


vitamins and nutrients [146, 147]. In Romanian ethnomedicine, Juglans regia is considered a panacea, a remedy that should be used for all types of diseases [74, 75, 84, 86]. Despite its traditional value, there is an obvious scarcity of studies regarding its benefits in the pediatric population. We have identified only one randomized, multicenter study evaluating the therapeutic efficacy of a herbal extract containing walnut leaves (in mixture with other six plants) in the treatment of acute non-bacterial tonsillitis in children aged 6 to 18 years [148]. The conclusion of the study was that the extract is safe and effective. There is some scientific evidence regarding the traditional use of $J$. regia in eczema, skin infections, scrophulosis, intestinal parasites, but not in the pediatric population. The therapeutic efficacy in adults of various Juglans regia extracts was proved for certain skin diseases, such as eczema [149] and atopic dermatitis [150]. The plant also showed in vitro or in vivo antimycobacterial [151] and antiparasitic activity $[152,153]$.

Chamomille (Matricaria chamomilla L., Asteraceae) (ERTV 71.42\%) use in pediatrics is well known all over the globe [154]. Its calming effects in child colic was demonstrated by two clinical studies, both using chamomille combined with other herbs [116, 155]. According to our findings, chamomille has been traditionally used in Romania to treat skin, respiratory, and neurological pediatric conditions, too. Concerning these diseases, international clinical studies have been performed mainly in adults. They have consistently shown positive results in the treatment of wounds [156], atopic dermatitis [157, 158], migraine [159], sleep disorders [160]. Regarding the indication in respiratory disorders, a recent study evaluated the effect of a herbal mixture including chamomille in asthmatic children during viral respiratory tract infection. According to the authors, a short course of this mixture reduced cough and nighttime awakening [161]. Nevertheless, it should be pointed out that the majority of the clinical studies evaluating chamomille's effects are deficient in quality and design [154, 162], and therefore the level of evidence is low. The antiepileptic potential of chamomille claimed by Romanian ethnomedicine remains to be investigated.

Having equal ERTV score with walnut tree and chamomile, broadleaf plantain (Plantago major L., Plantaginaceae) (ERTV 71.42\%) is also an old European medicinal plant that has been known for centuries, especially for its wound healing properties [163]. In Romanian ethnopediatry, the plant leaves were considered to be beneficial against cough, oliguria, intestinal worms, trauma, and debility $[75,86]$. Modern studies provided some evidence for its wound healing [164, 165], antibronchitis [166], anti-inflammatory [167, 168], immunoenhancing [169], and antiparasitic potential [170]. On the contrary, one adult clinical study reported the lack of diuretic effect, which is claimed by various ethnomedical systems [171]. No pediatric clinical study is available until now.

Blue eryngo (Eryngium planum, fam. Apiaceae) (ERTV $71.42 \%$ ) is less scientifically studied than the previous plants. Its traditional pediatric use in skin infections, digestive colics, weakness, nutritional imbalances, and neurological diseases has no evidence until now.

\section{Reflections on the names of the plants}

Vernacular names of plants used in Romanian ethnomedicine are deeply rooted in Romanian language. Thus, the botanist Valeriu Butura noticed in 1935 that this aspect is noticeable even in the Romanian regions where ethnic minorities were living (e.g., the Székelys, a subgroup of the Hungarian people, living in Odorhei interwar county): "...the genuine Romanian names do not betray any foreign influence. There are only rare cases when they (author note: Romanian villagers) have adopted the terminology of the foreigners with whom they come in daily contact..." [83]. Pantu noticed in 1929 that many folk names of plants are quite similar to the Latin names of the plants: fag (Fagus sylvatica L.), fasole (Phaseolus vulgaris L.), frasin (Fraxinus excelsior L.), pin (Pinus spp), trifoi (Trifolium spp), ulm (Ulmus spp.), ceapă (Allium cepa L.), corn (Cornus mas L.), cicoare (Cichorium intybus L.), iederă (Hedera helix L.), vâsc (Viscum album L.), mentă (Mentha piperita L.), urzică (Urtica dioica L.), etc. [172]. Since Romanian language is a Latin language, the propagation of Latinity through botanical terminology even until nowadays is not an unexpected fact [173].

Nevertheless, there are regional differences in folk plant names, sometimes caused by different spoken subdialects (rom. graiuri) of Romanian language (ex. Moldavian subdialect, Valachian subdialect, Transylvanian subdialect, etc.). For instance, Chelidonium majus L., known allover Romania by its most common folk name as rostopască, is also called rostopaciu, rostopaște, rostopaste in Transylvania, rostopastă in Banat, rostopasnă, rostopasnică in Bucovina, and rătăpască in Biharia [86].

We encountered several ambiguous cases of folk plant names-as the corresponding taxa could not be identified, those plant names and the pertaining information and/or reference were eliminated from our database. For instance, paparoane was reported by G. Bujorean to be used for the treatment of measles (Rom. bubatu al mic), but also he mentioned that this folk name corresponds to three different taxa: Glaucium corniculatum, Papaver rhoeas, Papaver somniferum [74]. The use of Papaver rhoeas for measles was unambiguously reported by other two authors who were cited in the present paper $[75,86]$ (and there is certainly a linguistic affinity between 
"paparoane" and "Papaver"), but we did not add G. Bujorean as a reference for this indication of $P$. rhoeas, neither did we include Glaucium corniculatum L. (Curtis) in our database. Nevertheless, the trust level of information found in Bujorean's work is high grace to its precision, since he made an exact botanical identification wherever possible, excepting the cases where the informant was not able to show or describe the plant. He marked these cases in the list with folk plant names found at the end of his book, in total about 50 such unresolved botanical identity cases.

We have also noticed a complex temporal dynamic of ethnobotanical/ethnomedical terminology in Romanian ethnopharmacology. Changes of folk names of plants and diseases occurred as well with the time: some appeared recently, others disappeared, and some remained constant through all the times. For instance, G. Bujorean reported new folk names of plants in 1936 [74], which were not found in a previous national reference work, published by Z. Pantu in 1929 [172]. Latter, A. Arvat reported more new names of plants (e.g. buruiană de cele sfinte for Chelidonium majus L.) and diseases (e.g. bube cu răutate) [80], when compared with those cited by G. Bujorean in 1936 [74].

Also, we estimate that some folk plant names have the tendency to disappear, especially those belonging to the following categories:

- Folk plant names signifying magic potential or sacred aspects/uses of plants, e.g., buruiana de cele sfinte or buruiene sfinte (engl. saint weed) (Chelidonium majus L.) [91].

- Folk plant names indicating diseases that were no longer treated by plants at a certain point in time, e.g., buruiana de ceas rău (engl. weed for bad hour/ epilepsy) (Tanacetum vulgare L.) [91].

- Folk plant names that contain folk disease names no longer in use, e.g., buruiana mătricii

(buruiana-weed, mătrice-cramps in newborns) (Tanacetum vulgare L.) [91].

Other scientists also noticed the occurrence of this ethnopharmacological terminology dynamics in other ethnomedical systems and proposed several potential reasons for this phenomenon:

1. Change of plant indications in time, due to traditional knowledge loss (e.g., failure of intergenerational transfer of knowledge) or advances in biomedicine (e.g., antibiotics, vaccines), which outdated some plant uses [174].

2. Medicalization of folk names (replacement of folk names by new medicalized names) [175].

\section{Reflections on the traditional names of diseases in Romanian ethnopediatry}

Romanian folk medicine, beyond its own specific local traits, has influences from humoral medicine, magic, and Christian religion [40, 97].

We have noticed that one of the specificities of the Romanian ethnomedicine is a concept that might be called "The Semiotic Triad," which links causative factors, diseases, and therapy by theoretical and language bonds (Fig. 2). The perspective of folk Romanian medicine over the pathogenesis is that the majority of the diseases are produced by demons or unclean spirits who invade the human body (children are considered to be the most susceptible), and who often give the name of the disease, and, sometimes, even the name of the plant that represents its remedy.

For example, samca is an evil female mythological being (derived from Ukrainean samka "evil spirit, devil" or slavonic samǔka "woman"), also known as aripa balaurului (Engl. devil's wing), who injures especially children, pregnant women, and women during postpartum period. This demon causes a disease having the same name samca [176]. According to the Romanian folk medicine, samca is a disease frequent especially among small children under four year old, characterized by tremors, spasms, involuntary contractions of muscles associated with livid colour of the body, stretching of the joints, fainting, foam at the mouth, startling during sleep, heavy sighing [84, 177-179], the description being quite similar with the clinical picture of epileptic crisis. Among the curative plants we mention, the perfect homonym plants samca (Galium intermedium Schult [86]., Eryngium planum L. [172]), and also the plants called sămcuța (diminutive of samca) (Sisymbrium officinale Scop., Veronica chamaedrys L.) [86, 176]. Another example of the same kind: child nightmares, weeping during night, and consequent insomnia, a.k.a muma-pădurii are produced by Muma-pădurii (Engl. Mother of the Forest), a terrifying female spirit living in the forest, who frightens the child during the night [97], and this disturbance may be cured by Galium odoratum L., also called muma pădurii in Romanian folk medicine [91]. It is worth mentioning that this semiotic triad, which reflects the style of thought in Romanian ethnomedicine, is surprisingly more or less similar with the specificity triad proposed by Mulinari, which represents a model of a framework in the style of modern medical thought [180].

Taking into account The Semiotic Triad, it is obvious why pronouncing the name of the disease is a tabu in Romanian ethnomedicine, having invocation power, and at the same time, knowing the name of the causative demon offers the controlling power over the disease: the healer can throw the demon out of the body through traditional incantations (Rom. descântece) [97]. 
Certain plants with remedial strength against diseases with demon names have also folk names suggesting this ethnoiatric interdiction concerning the utterance of the disease name, for instance Veronica chamaedrys L. is called tunezisă (Engl. "you unuttered", meaning "you with unuttered name") [176].

Other possible ethno-ethiopathogenic factors are the charms performed by other people, divine punishments for bad actions (in case of a child, the parental bad actions), negative emotions (e.g., fright could induce răul copiilor- epilepsy), non-observance of certain hygienic rules (e.g., the baby breastfed by a mother with dishevelled hair would develop bubă-various dermatological conditions), climatic factors, such as wind, cold, heat (e.g., the child who eats snow or ice would develop gîlci-tonsillitis, the stroke-luat din vânt is caused by the wind) [97]. Some are clearly obsolete, but others may have, more or less, a scientific basis, such as lack of hygiene, cold exposure, sun exposure etc. [181, 182].

Certain folk names of diseases may reflect the ethnoethiopathogenic factors: boala sfântă (Engl. saint disease)-epilepsy, vânt rău, vânt sec (Engl. bad wind, dry wind)-epilepsy, luat din vânt (Engl. taken from the wind)-stroke, soare in cap (Engl. sun in the head)-heat stroke, etc. $[75,94]$.

\section{Sacrotherapy and magic therapeutic rituals in Romanian ethnopediatry}

It is worth mentioning that Romanian folk medicine, as well as ethnopediatry, is also rich in sacrotherapy habits. According to the tradition, the therapeutic efficacy of medicinal plants is increased by sanctification in the church during various religious celebrations, by hanging them at the icons, or by traditional incantations (Rom. descântece) $[11,79,85,86]$. Certain magical formulas contain plants that are believed to be sacred or to bring health or luck. For instance, număruşul is such a magical formula transmitted in a well-known family of icon painters, living in Valea Sebeşului. The formula was worn by the child in a sachet, as an amulet, to protect him. It contained a text with the names of God in all languages, together with basil, spring wheat and frankincense [10].

\section{Romanian ethnopediatry and bioprospection}

Analysis of our database led to the identification of several medicinal plants traditionally used in Romanian folk medicine to treat child epilepsy: Aconitus napelus, Artemisia absinthium, Aruncus dioicus, Butomus umbellatus, Carlina acaulis, Centaurium erythraea, Cichorium intybus, Dryopteris filix-mas, Gratiola officinalis, Galium intermedium, Levisticum officinale, Lycium barbarum, Matricaria chamomilla, Melissa officinalis, Pilosella officinarum, Salix alba, Sisymbrium officinale, and Tanacetum vulgare. Regarding these plants, their antiepileptic potential was not scientifically evaluated, except for a few studies on Aconitum alkaloids' antiepileptic activity on rat hypocampal slices [183-185], one in vitro study on the inhibitory potential of Melissa officinalis extract on the rat brain GABA transaminase, an enzyme target in the therapy of epilepsy [186], and another one on the affinity of Tanacetum vulgare on the GABA(A)-benzodiazepine receptor, an alternative target in the anticonvulsant therapy [187].

Another discovery concerns the antitubercular potential of five species: Dryopteris filix-mas, Cochlearia officinalis, Ficus carica, Juglans regia, and Pulmonaria

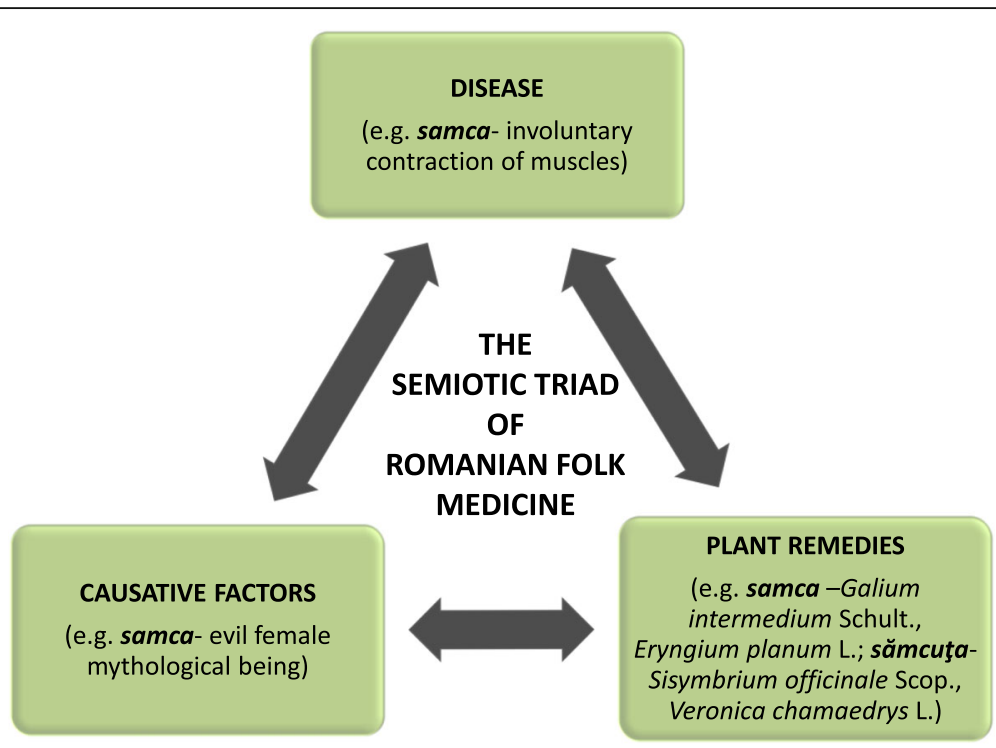

Fig. 2 The semiotic triad of Romanian folk medicine 
officinalis $L$. used to treat either tuberculosis in general or scrophulosis in Romanian ethnopediatry one century ago. This fact might be of some interest since the multidrug-resistant forms of this disease have been recently increasing in incidence in many parts of the globe [188], and new bioactive antitubercular compounds are needed.

\section{Prevention in Romanian ethnopediatry}

We would like to highlight also that Romanian ethnopediatry has an important preventive component, several medicinal plants being used to avoid illnesses or to strengthen the body. We have found that 23 medicinal plants from a total of 153 are traditionally used as baths for general or musculoskeletal strengthening. Other examples of preventive ethnopediatry mentioned in the historical ethnographic texts are related to the management of infectious diseases: Romanian mothers used to string garlic cloves (believed to be the best remedy against boli lipicioase-contagious diseases) on a thread, which was afterwards attached to the baby's throat to keep him/her away from boala de grumaz-diphtheria [189]; the baked squash (Cucurbita maxima, fam. Cucurbitaceae) was applied on the child's face in order to prevent chicken pox, especially during certain days (on the 4-6th of December, known as the "days of the chicken pox", Rom. zilele bubatului) [75].

\section{Limitations}

Our study has several limitations:

1. In certain cases, the text contained only the vernacular name of the plant, or different species had the same vernacular name. Those species whose identification credibility was very low or impossible to determine were left aside. For instance, according to Bujorean G, the vernacular name iarba faptului designates five species Galium aparine, Sedum album, Geum urbanum, Potentilla erectum, and Anthyllis vulneraria [74].

Consequently, although the plant iarba faptului was mentioned to be used in bath for children with skin diseases, this information was left aside.

2. We cannot claim that our data are exhaustive. The whole data on the use of medicinal plants which exists in Romanian archives has never been digitized, nor rigorously systematized. Until this process is performed, it is impossible to state that only the medicinal plants listed in this paper were historically used for children diseases on the territory of Romania in the period 1860s-1970s.

3. The number of the medicinal plants identified by us to have been used for children diseases in 1860s1970s in Romania is an underestimation of the real number, since most probably many other plants could be indicated in child diseases, despite the fact that the ethnographers did not mentioned this. We have included in our study only the plants for which we have found the explicit specification of plant use in children. Therefore, we might have eliminated many plants widely used in children disorders, but for which this pediatric use was not specifically mentioned in our sources. This inclusion criterion was applied in order to have correct data, and to reduce to zero the risk of selecting a wrong medicinal plant. A direct question to the informant would have been necessary to establish whether a given plant used in adults was also used in children. Under these circumstances and objective constraints, we adhered to the principle that "more is not always better." Our data might not be highly representative ("accurate"), but they are correct ("precise").

\section{Conclusions}

The present study on medicinal plants used in Romanian ethnopediatry exposes for the first time to the international scientific community important ethnobotanical information contained in several Romanian bibliographical resources, which are not yet translated into English, and are therefore less visible to the world experts.

Few medicinal plants (e.g., Dryopteris filix-mas, Gratiola officinalis, Juglans regia, Eryngium planum, $\mathrm{Ne}$ peta cataria), which were found in the present study to be significant in terms of their traditional therapeutic potential in children, are not yet (fully) studied, but their future clinical and pediatric evaluation may reveal unexpected medical benefits, especially in the case of certain diseases that still pose therapeutic challenges (e.g., epilepsy, tuberculosis). The difficulties related to pediatric clinical studies are always going to be present, due to ethical concerns, design issues (related to the continuously changing physical and biochemical features in a developing organism). Centuries-old ethnopharmacological expertise on herbal efficacy and safety could partially compensate these aspects and represent at least a starting point for further research.

The results of our search suggest that the ethnopediatric practices in Romania represent an important heritage that need to be further explored and supported in order to avail their maximum benefits. A concerted effort of botanists, pharmacologists, biochemists, and pediatric physicians is required for the assessment of available historical ethnobotanic and ethnopharmacological data. This transdisciplinary scientific analysis may lead to the discovery of new, efficient therapeutic agents for children diseases. 


\section{Abbreviations}

BS: Number of targeted body systems; ERTV: Ethnopediatric relative therapeutic versatility

\section{Acknowledgments}

Not applicable.

\section{Authors' contributions}

MP and DD are both principal authors and contributed equally to the study. $M G, M P$ drafted the outline. MG conceived the methodology and coordinated the study. MD and MG performed the manual search of the bibliographical resources and electronic search, while DD verified the information collected and the correct presentation of taxonomic, botanical data. MP calculated the index used in the present work. All three authors contributed to the interpretation of the results, elaborated and improved the initial manuscript, prepared the revised form of the manuscript, and eventually agreed on the final version of this paper.

\section{Funding}

No source of funding was used for this publication.

\section{Availability of data and materials}

All data generated or analyzed during this study are included in this published article.

\section{Ethics approval and consent to participate}

Not applicable.

\section{Consent for publication}

Not applicable.

\section{Competing interests}

The authors declare that hat they have no competing interests. The research was conducted in the absence of any commercial or financial relationships that could be construed as a potential conflict of interest.

\section{Author details}

'Department of Functional Sciences I- Biochemistry, Faculty of Medicine, Carol Davila University of Medicine and Pharmacy, Bucharest, Romania. ${ }^{2}$ Nephrology Clinic, University Emergency Hospital Bucharest, 050098 Bucharest, Romania. ${ }^{3}$ Department of Medical Semiology, Faculty of Medicine, Carol Davila University of Medicine and Pharmacy, Bucharest, Romania.

Received: 18 November 2019 Accepted: 12 March 2020

Published online: 24 March 2020

\section{References}

1. Staub PO, Casu L, Leonti M. Back to the roots: a quantitative survey of herbal drugs in Dioscorides' De Materia Medica (ex Matthioli, 1568). Phytomedicine. Elsevier. 2016;23:1043-52.

2. Leonti M, Verpoorte R. Traditional Mediterranean and European herbal medicines. J Ethnopharmacol. Ireland. 2017;199:161-7.

3. Touwaide A, De Santo NG, Aliotta G. The origins of Western herbal medicines for kidney diseases. Adv Chronic Kidney Dis W.B. Saunders. 2005; 12:251-60.

4. De Vos P. European materia medica in historical texts: longevity of a tradition and implications for future use. J Ethnopharmacol Ireland. 2010; 132:28-47.

5. Tewari D, Hohmann J, Kiss AK, Rollinger JM, Atanasov AG. Editorial: Ethnopharmacology in Central and Eastern Europe in the Context of Global Research Developments. Front Pharmacol. 2019;10:9-11.

6. Regneala M. Biblioteconomia în Secolul XXI şi Biblioteca Academiei Române. In: Colecțiile patrimoniu în era Digit. Bucuresti, Romania: Biblioteca Academiei Romane; 2014. p. 5-11.

7. Lardos A, Heinrich M. Continuity and change in medicinal plant use: the example of monasteries on Cyprus and historical iatrosophia texts. J Ethnopharmacol. 2013:150:202-14.

8. Gheorghiu E, Mihai F. Manuscrise cu elemente de farmacoterapie populară aflate în Biblioteca Academiei Republicii Socialiste România și Arhivele Statului din Bucureşti. Farmacia. 1969;XVII:297-306.
9. Păcală V. Monografia satului Răşinari. Sibiu, Romania: Tiparul Tipografiei Arhidiecezane; 1915

10. Pavelescu G. Valea Sebeşului. Monografie Etnofolclorică, vol.II. Folclor. Sibiu, Romania: Ed. Astra Museum; 2004.

11. Gradinaru N. Medicina populară din Basarabia de la sfârșitul secolului al XIXlea - începutul secolului al XX-lea. Aspecte istorico-etnografice [Internet]. Academia de Stiințe a Moldovei, Chisinau; 2015. Available from: http://www. cnaa.md/files/theses/2015/22833/natalia_gradinaru_thesis.pdf.

12. Kalle R, Sõukand R. Historical ethnobotanical review of wild edible plants of Estonia (1770s-1960s). Acta Soc Bot Pol. 2012;81.

13. Pieroni A. Traditional uses of wild food plants, medicinal plants, and domestic remedies in Albanian, Aromanian and Macedonian villages in South-Eastern Albania. J Herb Med. Elsevier. 2017:9:81-90.

14. Kathe W, Honnef S, Heym A. Medicinal and aromatic plants in Albania, Bosnia-Herzegovina, Bulgaria, Croatia and Romania: a study of the collection of and trade in medicinal and aromatic plants (MAPs), relevant legislation and the potential of MAP use for financing nature conservation. Ger. Fed. Agency Nat. Conserv. Bonn; 2003

15. Mallarach JM, Corcó J, Papayannis T. Christian monastic communities living in harmony with the environment: An overview of positive trends and best practices. Stud Monast. 2014:56:353-91.

16. Sauciuc B, Catanoiu S. The monastic area of Vanatori Neamt Nature Park, Romania. In: Mallarach J-M, editor. Prot Landscapes Cult Spirit Values, Vol 2. Kasparek Verlag; 2008. p. 146-9.

17. Adams M, Berset C, Kessler M, Hamburger M. Medicinal herbs for the treatment of rheumatic disorders--a survey of European herbals from the 16th and 17th century. J Ethnopharmacol Ireland. 2009;121:343-59.

18. Buenz EJ, Schnepple DJ, Bauer BA, Elkin PL, Riddle JM, Motley TJ. Techniques: Bioprospecting historical herbal texts by hunting for new leads in old tomes. Trends Pharmacol Sci England. 2004;25:494-8.

19. Spalek K, Spielvogel I, Prockow M, Prockow J. Historical ethnopharmacology of the herbalists from Krummhubel in the Sudety Mountains (seventeenth to nineteenth century), Silesia. J Ethnobiol Ethnomed England. 2019;15:24.

20. Łuczaj $Ł$. Changes in the utilization of wild green vegetables in Poland since the 19th century: a comparison of four ethnobotanical surveys. J Ethnopharmacol Elsevier. 2010:128:395-404

21. Łuczaj Ł, Szymański WM. Wild vascular plants gathered for consumption in the Polish countryside: a review. J Ethnobiol Ethnomed. 2007:3:17.

22. Łuczaj L, Kujawska M. Botanists and their childhood memories: an underutilized expert source in ethnobotanical research. Bot J Linn Soc. 2012; 168:334-43.

23. Sõukand R, Kalle R. Change in medical plant use in Estonian ethnomedicine: a historical comparison between 1888 and 1994. J Ethnopharmacol. 2011; 135:251-60.

24. Kalle R, Sõukand R. Wild plants eaten in childhood: a retrospective of Estonia in the 1970s-1990s. Bot J Linn Soc. Oxford University Press. 2013; 172:239-53.

25. Šarić-Kundalić B, Dobeš C, Klatte-Asselmeyer V, Saukel J. Ethnobotanical study on medicinal use of wild and cultivated plants in middle, south and west Bosnia and Herzegovina. J Ethnopharmacol. 2010;131:33-55.

26. Savić J, Mačukanović-Jocić M, Jarić S. Medical ethnobotany on the Javor Mountain (Bosnia and Herzegovina). Eur J Integr Med. 2019;27:52-64.

27. Shikov AN, Pozharitskaya ON, Makarov VG, Wagner H, Verpoorte R, Heinrich M. Medicinal plants of the Russian Pharmacopoeia; their history and applications. J Ethnopharmacol. Elsevier. 2014;154:481-536.

28. Shikov AN, Tsitsilin AN, Pozharitskaya ON, Makarov VG, Heinrich M. Traditional and current food use of wild plants listed in the Russian pharmacopoeia. Front Pharmacol Front. 2017;8:841.

29. Crisan IH. Medicina in Dacia. Crisan E, Alicu D, editors. București: Dacica; 2007.

30. Alexan M, Bojor O, Craciun F. Flora medicinala a Romaniei, vol... Editura Ceres; 1988.

31. Ristin D. Fragmentele de medicina popualra din manuscrisele slavone din Banat. Romanoslavica. 2010;XLVl:103-12

32. Djamo-Diaconita L. Un text slavon de farmacoterapie populara din secolul al XVI-lea. Romanoslavica. 1967:XIV:377-409.

33. Corbea T. In: Gherman A, editor. Dictiones latinae cum valachica interpretatione. Cluj-Napoca: Atlas-Clusium; 2001.

34. Chivu G. Nume de plante în texte vechi româneşti. Felecan O, editor. Numele si numirea. Actele Conferintei Internationale Onomast. Ediția a II-a Onomast. din spațiul public actual. Editura Mega, Editura Argonaut; 2013. 
35. Pop E. Cei dintâi culegători ai numelor româneşti de plante. Țara Bârsei. 1930;2:164-74.

36. Barca C, Strachinaru V. Ethnoiatric data and botanical folklore in the district of jassy. Rev Med Chir Soc Med Nat lasi. Romania. 1974;78:933-6.

37. Bogdan I, Nechifor A, Basea I, Hruban E. From Rumanian folk medicine: Non-specific stimulus therapy using transcutaneous implantation of hellebore (Helleborus purpurascens, Fam. Ranunculaceae) in agriculturally useful animals. Dtsch Tierarztl Wochenschr. Germany. 1990;97:525-9.

38. Mihaiescu M, Imbrea I-M. Medicinal plants from Tara Hategului used in folk medicine. Res J Agric Sci. 2015;47:228-32.

39. Tiță I, Mogoşanu GD, Tiță MG. Ethnobotanical inventory of medicinal plants from the South-West of Romania. Farmacia. 2009:57:141-56.

40. Lisovschi A. Etnoiatria, Magia si Descantecul. Cluj Napoca, Romania, Ed. Napoca Star; 2004

41. Drăgulescu C. Botanica populară românească în sudul Transilvaniei. Sibiu, Romania: Ed. Universității Lucian Blaga; 2013.

42. Bartha SG, Quave CL, Balogh L, Papp N. Ethnoveterinary practices of Covasna County, Transylvania, Romania. J Ethnobiol Ethnomed. England. 2015;11:35.

43. Papp N, Bartha S, Boris G, Balogh L. Traditional uses of medicinal plants for respiratory diseases in Transylvania. Nat Prod Commun. United States. 2011; 6:1459-60.

44. Papp N, Birkás-Frendl K, Farkas Á, Czégényi D. Hungarian ethnobotanical studies in Romania. In: Pieroni A, Quave CL, editors. Ethnobot biocultural Divers Balk Perspect Sustain Rural Dev Reconcil. 2014. p. 1-255.

45. Pieroni A, Quave CL, Giusti ME, Papp N. "We Are Italians!": the hybrid ethnobotany of a Venetian Diaspora in Eastern Romania. Hum Ecol. 2012;40: 435-51.

46. Luczaj L, Stawarczyk K, Kosiek T, Pietras M, Kujawa A. Wild food plants and fungi used by Ukrainians in the western part of the Maramures region in Romania. Acta Soc Bot Pol. 2015;84:339-46.

47. Soukand R, Pieroni A. The importance of a border: Medical, veterinary, and wild food ethnobotany of the Hutsuls living on the Romanian and Ukrainian sides of Bukovina. J Ethnopharmacol. Ireland. 2016;185:17-40.

48. Pieroni A, Nedelcheva A, Dogan Y. Local knowledge of medicinal plants and wild food plants among Tatars and Romanians in Dobruja (South-East Romania). Genet Resour Crop Evol. 2015;62:605-20.

49. Pieroni A, Dibra B, Grishaj G, Grishaj I, Maçai SG. Traditional phytotherapy of the Albanians of Lepushe. Northern Albanian Alps. Fitoterapia. 2005;76:379-99.

50. Pieroni A, Sõukand R. The disappearing wild food and medicinal plant knowledge in a few mountain villages of North-Eastern Albania. J Appl Bot Food Qual. 2017;90:58-67.

51. Napoli M. The plants, rituals and spells that "cured" helminthiasis in Sicily. J Ethnobiol Ethnomed. England. 2008;4:21.

52. Jarić $\mathrm{S}$, Mitrović $\mathrm{M}$, Pavlović $\mathrm{P}$. An ethnobotanical and ethnomedicinal study on the use of wild medicinal plants in rural areas of Serbia. In: Pieroni A, Quave CL, editors. Ethnobot Biocultural Divers Balk. Springer; 2014. p. 87-112.

53. Kolosova VB. Name-Text-Ritual: The role of plant characteristics in slavic folk medicine. Folk Slavic, East Eur Eurasian Folk Assoc. 2005;10:44-61.

54. Rexhepi B, Mustafa B, Hajdari A, Rushidi-Rexhepi J, Quave CL, Pieroni A. Traditional medicinal plant knowledge among Albanians, Macedonians and Gorani in the Sharr Mountains (Republic of Macedonia). Genet Resour Crop Evol. 2013;60:2055-80.

55. Pieroni A. Local plant resources in the ethnobotany of Theth, a village in the Northern Albanian Alps. Genet Resour Crop Evol. 2008;55:1197-214.

56. Pieroni A, Sõukand R, Quave CL, Hajdari A, Mustafa B. Traditional food uses of wild plants among the Gorani of South Kosovo. Appetite. 2017; 108:83-92.

57. Pieroni A, Rexhepi B, Nedelcheva A, Hajdari A, Mustafa B, Kolosova V, et al. One century later: the folk botanical knowledge of the last remaining Albanians of the upper Reka Valley, Mount Korab, Western Macedonia. J Ethnobiol Ethnomed. BioMed Central. 2013;9:22.

58. Pieroni A, Ibraliu A, Abbasi AM, Papajani-Toska V. An ethnobotanical study among Albanians and Aromanians living in the Rraicë and Mokra areas of Eastern Albania. Genet Resour Crop Evol. 2015;62:477-500.

59. Pieroni A, Cianfaglione K, Nedelcheva A, Hajdari A, Mustafa B, Quave CL. Resilience at the border: Traditional botanical knowledge among Macedonians and Albanians living in Gollobordo. Eastern Albania. J Ethnobiol Ethnomed. 2014;10:31.
60. Kozuharova E. Descriptive study of contemporary status of the traditional knowledge on medicinal plants in Bulgaria. African J Pharm Pharmacol. 2013;7:185-98

61. Kozuharova E, Benbassat N, Napier J. New records of the remedial properties of vascular plants, some traditionally accepted as medicinal plants and some less familiar to ethnobotanists. Phytol Balc Int J Balk Flora Veg. 2012;18:323-32.

62. Popovic Z, Smiljanic M, Matic R, Kostic M, Nikic P, Bojovic S. Phytotherapeutical plants from the Deliblato Sands (Serbia): Traditional pharmacopoeia and implications for conservation. Indian J Tradit Knowl. 2012;11:385-400.

63. Popović Z, Smiljanić M, Kostić M, Nikić P, Janković S. Wild flora and its usage in traditional phytotherapy (deliblato sands, Serbia, south east europe). Indian J Tradit Knowl. 2014;13:9-35.

64. Pieroni A, Giusti ME, Quave CL. Cross-cultural ethnobiology in the Western Balkans: medical ethnobotany and ethnozoology among Albanians and Serbs in the Pešter Plateau, Sandžak. South-Western Serbia. Hum Ecol. 2011;39:333.

65. Svanberg I, Sõukand R, Łuczaj Ł, Kalle R, Zyryanova O, Dénes A, et al. Uses of tree saps in northern and eastern parts of Europe. Acta Soc Bot Pol. 2012;81: 343-57.

66. Mohammadi G, Ghazanfarpour M, Kargarfard L, Babakhanian M. Effectiveness of herbal medicines containing phytoestrogens to treat infantile colic: a meta-analysis review. J Pediatr Rev. 2018;7:01-10.

67. Anheyer D, Frawley J, Koch AK, Lauche R, Langhorst J, Dobos G, et al. Herbal medicines for gastrointestinal disorders in children and adolescents: A systematic review. Pediatrics. 2017;139:e20170062.

68. Anheyer D, Lauche R, Schumann D, Dobos G, Cramer H. Herbal medicines in children with attention deficit hyperactivity disorder (ADHD): A systematic review. Complement Ther Med. 2017;30:14-23.

69. Anheyer D, Cramer H, Lauche R, Saha FJ, Dobos G. Herbal medicine in children with respiratory tract infection: systematic review and metaanalysis. Acad Pediatr. 2018;18:8-19.

70. Schapowal A, Klein P, Johnston SL. Echinacea reduces the risk of recurrent respiratory tract infections and complications: a meta-analysis of randomized controlled trials. Adv Ther. 2015;32:187-200.

71. Hofmann D, Hecker M, Völp A. Efficacy of dry extract of ivy leaves in children with bronchial asthma - A review of randomized controlled trials. Phytomedicine. 2003;10:213-20

72. Convention on Biological Diversity Fifth National Report-Romania [Internet]. Bucharest, Romania; 2014. Available from: https://www.cbd.int/ doc/world/ro/ro-nr-05-en.pdf.

73. Convention on Biological Diversity First National Report-Romania [Internet]. Bucharest, Romania; 1998. Available from: https://www.cbd.int/ doc/world/ro/ro-nr-01-en.pdf.

74. Bujorean G. Boli, leacuri si plante de leac cunoscute de taranimea romana. Publ Period a Asoc Astra [Internet]. Editura Asociatiunii Astra Sibiu. 1936;26: 1-398 Available from: http://dspace.bcucluj.ro/handle/123456789/68446.

75. Butura V. Enciclopedie de etnobotanica romaneasca. Bucuresti: Editura Stiintifica si Enciclopedica; 1979.

76. Dihoru G, Boruz V. The list of main spontaneous medicinal plants form Romania. Ann Univ Craiova - Agric Mont Cadastre Ser [Internet]. 2014;44: 328-44. Available from: http://anale.agro-craiova.ro/index.php/aamc/article/ view/309.

77. Lange D. The role of East and Southeast Europe in the medicinal and aromatic plant trade: with special focus on Albania, Bosnia-Herzegovina, Bulgaria, Croatia and Romania. In: Kathe W, Honnef S, Heym A, editors. Med Aromat plants Albania, Bosnia-Herzegovina, Bulg Croat Rom a study Collect trade Med Aromat plants (MAPs), Relev Legis potential MAP use Financ Nat Conserv. Bonn: German Federal Agency of Nature Conservation; 2003. p. 64-77.

78. Butura V. Plante cunoscute şi întrebuințate de locuitorii câtorva sate româneşti (Ethnobotanische mitteilungen aus Rumanien). Bul Grădinii Bot şi al Muzeului Bot la Univ din Cluj. 1938;XVIII:99-106.

79. Butura V. Plante cunoscute si intrebuintate de romanii din Transilvania. Bull du Jard du Mus Bot L'Universitee Cluj, Roum. 1936;XVl:70-7.

80. Arvat AA. Plantele medicinale și medicina populară la Nișcani. Bul Institutului Soical Român din Basarabia. 1937;:1:1-57.

81. Borza A. Noutăti etnobotanice românești: o farmacie băbească. Bul Grădinii Bot Cluj. 1936;XXVl:17-27.

82. Laugier C. Contributiuni la etnografia medicala a Olteniei. Craiova: Editura Scrisul Romanesc; 1925. 
83. Butura V. Plante cunoscute şi întrebuințate de românii din Ardeal. Note etnobotanice. Bul Grădinii Bot Cluj. 1935;XV:218-27.

84. Leon N. Istoria naturala medicala a poporului roman. In: Analele Acad Rom Ser II, Memoriile Sect Stiint. Bucuresti: Institutul de Arte Grafice Carol Gobl: 1903. p. 163

85. Marian SF. In: Brădățan A, editor. Botanica Poporana Romana, vol I. Suceava: Muşatinii; 2008.

86. Marian SF. In: Brădățan A, editor. Botanica Poporana Romana, vol II-III. Bucuresti: Editura Academiei Române; 2010.

87. Condrea A. Studii de etnobotanica in comuna Poiana Cristei, jud. Vrancea. Muzeul Vranc Stud Şi Comun. 1991;8-10:281-6.

88. Ulieru G. Florile bune de leac. Campulung-Muscel, Romania: Tipografia Gheorghe N. Vladescu si Fiul; 1929.

89. Negru A. Cercetarea sociala institutionalizata in Transilvania si Banat. In: Bădescu I, Cucu-Oancea O, Şişeştean G, editors. Tratat Sociol Rural. Bucuresti, Romania: Editura Mica Valahie; 2009. p. 679-94.

90. Dragendorff G. Die Heilpflanzen der verschiedenen Völker und Zeiten. Ihre Anwendung, wesentlichen Bestandtheile und Geschichte (Medicinal plants of various peoples and times). Stuttgart: Verlag von Ferdinand Enke; 1898.

91. Borza A. Dicționar etnobotanic. Bucuresti, Romania: Editura Academiei Republicii Socialiste România; 1969.

92. Euro+Med. Euro+Med PlantBase - the information resource for EuroMediterranean plant diversity. http://ww2.bgbm.org/EuroPlusMed/. 2006.

93. The Plant List. Version 1.1. [Internet]. Publ. Internet. 2013 [cited 2020 Jan 1]. Available from: http://www.theplantlist.org/.

94. Georgescu-Viste I. Terminologie medicala populara. Bucuresti: Ed. Maiko; 2007.

95. WHO | International Classification of Primary Care, Second edition (ICPC-2) [Internet]. WHO. World Health Organization; 2012 [cited 2019 Jun 21]. Available from: https://www.who.int/classifications/icd/ adaptations/icpc2/en/.

96. Staub PO, Geck MS, Weckerle CS, Casu L, Leonti M. Classifying diseases and remedies in ethnomedicine and ethnopharmacology. J Ethnopharmacol. 2015;

97. Candrea A. Folclorul medical român comparat: privire generală, medicina magică. Bucuresti, Romania, Casa Scoalelor; 1944

98. Sharquie KE, Al-Obaidi HK. Onion juice (Allium cepa L.), a new topical treatment for alopecia areata. J Dermatol. 2002;29:343-6.

99. Thomas A, Thakur S, Habib R. Comparison of antimicrobial efficacy of green tea, garlic with lime, and sodium fluoride mouth rinses against Streptococcus mutans, Lactobacilli species, and Candida albicans in children: a randomized double-blind controlled clinical trial. Int J Clin Pediatr Dent. India. 2017;10:234-9.

100. Silverberg NB. Garlic cloves for verruca vulgaris. Pediatr Dermatol. 2002;19: 183.

101. Sani MN, Kianifar HR, Kianee A, Khatami G. Effect of oral garlic on arterial oxygen pressure in children with hepatopulmonary syndrome. World J Gastroenterol. 2006;12:2427-31

102. Liy-Wong C, Lara-Corrales I. I P. Society for pediatric dermatology 43 rd Annual Meeting Poster Presentations July 2018 | Lake Tahoe, California. Pediatr Dermatol. 2018;35:702-31.

103. Motaharifard MS, Effatpanah M, Karimi M, Akhondzadeh S, Rahimi H, Yasrebi SA, et al. Effect of sweet almond syrup versus methylphenidate in children with ADHD: A randomized triple-blind clinical trial. Complement Ther Clin Pract. 2019:36:170-5.

104. Sahib A, Mohammed I, Sloo S. Antigiardial effect of Anethum graveolens aqueous extract in children. J Intercult Ethnopharmacol. 2014;3:109.

105. Panahi Y, Sharif MR, Sharif A, Beiraghdar F, Zahiri Z, Amirchoopani G, et al. A randomized comparative trial on the therapeutic efficacy of topical aloe vera and calendula officinalis on diaper dermatitis in children. Sci World J. 2012;2012:810234.

106. Sharifi-Heris Z, Farahani LA, Haghani H, Abdoli-Oskouee S, HasanpoorAzghady SB. Comparison the effects of topical application of olive and calendula ointments on Children's diaper dermatitis: a triple-blind randomized clinical trial. Dermatol Ther. 2018;31:e12731.

107. Adib-Hajbaghery M, Mahmoudi M, Mashaiekhi M. The effects of Bentonite and Calendula on the improvement of infantile diaper dermatitis. J Res Med Sci. 2014;19:314-8

108. Prozornaia LP, Brzhevskii W. Efficacy of physiotherapy and hygienic procedures in treatment of adults and children with chronic blepharitis and dry eye syndrome. Vestn Oftalmol. 2013;129:68-70 72-3.
109. Tzadok M, Uliel-Siboni S, Linder I, Kramer U, Epstein O, Menascu S, et al. CBD-enriched medical cannabis for intractable pediatric epilepsy: The current Israeli experience. Seizure. 2016;35:41-4.

110. Libzon S, Schleider LBL, Saban N, Levit L, Tamari Y, Linder I, et al. Medical cannabis for pediatric moderate to severe complex motor disorders. J Child Neurol. 2018;33:565-71.

111. Khmel'nitskaia NM, Vorob'ev K V, Kliachko LL, Ankhimova ES, Kosenko VA, Tyrnova $E V$, et al. [A comparative study of conservative treatment schemes in chronic tonsillitis in children]. Vestn Otorinolaringol. RUSSIA; 1998;39-42.

112. Gundogdu Z. Effect of a synbiotic on infantile acute gastroenteritis. Benef Microbes. 2013:4:231-5.

113. Asgary S, Kelishadi R, Rafieian-Kopaei M, Najafi S, Najafi M, Sahebkar A. Investigation of the lipid-modifying and antiinflammatory effects of cornus mas L. supplementation on dyslipidemic children and adolescents. Pediatr Cardiol. 2013;34:1729-35

114. Usmani HA. Preliminary observations on the treatment of diarrhoea in children with carrot soup. Indian J Pediatr. 1955;22:244-6.

115. Abbasi S, Kamalinejad M, Babaie D, Shams SM, Sadr Z, Gheysari M, et al. A new topical treatment of atopic dermatitis in pediatric patients based on Ficus carica L. (Fig): a randomized, placebo-controlled clinical trial. Complement Ther Med. 2017;35:85-91.

116. Savino F, Cresi F, Castagno E, Silvestro L, Oggero R. A randomized doubleblind placebo-controlled trial of a standardized extract of Matricariae recutita, Foeniculum vulgare and Melissa officinalis (ColiMil) in the treatment of breastfed colicky infants. Phyther Res. England. 2005;19:335-40.

117. Martinelli M, Ummarino D, Giugliano FP, Sciorio E, Tortora C, Bruzzese D, et al. Efficacy of a standardized extract of Matricariae chamomilla L., Melissa officinalis L. and tyndallized Lactobacillus acidophilus (HA122) in infantile colic: an open randomized controlled trial. Neurogastroenterol Motil. 2017; 29:Epub 2017 Jun 30.

118. Schapowal A, Berger D, Klein P, Suter A. Echinacea/sage or chlorhexidine/ lidocaine for treating acute sore throats: a randomized double-blind trial. Eur J Med Res. 2009;14:406-12.

119. Damsgaard CT, Biltoft-Jensen A, Tetens I, Michaelsen KF, Lind MV, Astrup A, et al. Whole-grain intake, reflected by dietary records and biomarkers, is inversely associated with circulating insulin and other cardiometabolic markers in 8- to 11-year-old children. J Nutr. 2017;147:816-24.

120. Saint-Raymond A, Seigneuret N. The European paediatric initiative: 1 year of experience. Paediatr Drugs. Switzerland. 2009;11:9-10.

121. Hein IM, Troost PW, Lindeboom R, Benninga MA, Zwaan CM, van Goudoever JB, et al. Accuracy of the MacArthur Competence Assessment Tool for Clinical Research (MacCAT-CR) for Measuring Children's Competence to Consent to Clinical Research. JAMA Pediatr. 2014;168:1147-53.

122. Chiaruttini G, Felisi M, Bonifazi D. Challenges in paediatric clinical trials: How to Make It Feasible. InTech: Manag Clin Trials; 2018.

123. Kern SE. Challenges in conducting clinical trials in children: approaches for improving performance. Expert Rev Clin Pharmacol. 2009;2:609-17.

124. Parvu C. Universul plantelor-mica enciclopedie. Editura Enciclopedica: Bucureşti; 1997.

125. Torpy JM, Campbell A, Glass RM. Chronic diseases of children. JAMA. 2010; 303:682.

126. Olson M, Chambers M, Shaibi G. Pediatric markers of adult cardiovascular disease. Curr Pediatr Rev. 2018;13:255-9.

127. Salantă L-C, Păucean A, Tofană M, Man S, Pop C. Romanian cuisine : culinary habits and local produce. J Agroaliment Process Technol. 2015;21:186-91.

128. McGowan L, Caraher M, Raats M, Lavelle F, Hollywood L, McDowell D, et al. Domestic cooking and food skills: A review. Crit Rev Food Sci Nutr. 2017;57: 2412-31.

129. Giusti F, Capuano E, Sagratini G, Pellegrini N. A comprehensive investigation of the behaviour of phenolic compounds in legumes during domestic cooking and in vitro digestion. Food Chem. 2019;285:458-67.

130. Díaz-Reviriego I, Fernández-Llamazares Á, Salpeteur M, Howard PL, ReyesGarcía V. Gendered medicinal plant knowledge contributions to adaptive capacity and health sovereignty in Amazonia. Ambio [Internet]. Springer Netherlands; 2016;45:263-75. Available from: https://www.ncbi.nlm.nih.gov/ pubmed/27878530.

131. PFEIFFER JM, BUTZ RJ. Assessing cultural and ecological variation in ethnobiological research: the importance of gender. J Ethnobiol [Internet]. 2005:25:240-78. Available from: https://doi.org/10.2993/02780771(2005)25[240:ACAEVI]2.0.CO. 
132. Bruschi P, Morganti M, Mancini M, Signorini MA. Traditional healers and laypeople: a qualitative and quantitative approach to local knowledge on medicinal plants in Muda (Mozambique). J Ethnopharmacol. Ireland. 2011; 138:543-63.

133. Dan Guimbo I, Mueller JG, Larwanou M. Ethnobotanical knowledge of men, women and children in rural Niger: a mixed-methods approach. Ethnobot Res Appl Vol 9 [Internet]. 2011;9:235-42. Available from: http://journals.sfu. ca/era/index.php/era/article/view/259.

134. Gorgus E, Hittinger M, Schrenk D. Estimates of ethanol exposure in children from food not labeled as alcohol-containing. J Anal Toxicol. 2016;40:537-42.

135. Gerace E, Landucci E, Totti A, Bani D, Guasti D, Baronti R, et al. Ethanol toxicity during brain development: alterations of excitatory synaptic transmission in immature organotypic hippocampal slice cultures. Alcohol Clin Exp Res. 2016;40:706-16

136. Srdjenovic B, Torovic L, Kladar N, Bozin B, Sudji J. Health risk assessment for pediatric population associated with ethanol and selected residual solvents in herbal based products. Regul Toxicol Pharmacol. Academic Press. 2019; 107:104406.

137. Delgado-Charro MB, Guy RH. Effective use of transdermal drug delivery in children. Adv Drug Deliv Rev. 2014;73:63-82.

138. Visscher MO, Adam R, Brink S, Odio M. Newborn infant skin: physiology, development, and care. Clin Dermatol. 2015;33:271-80.

139. Proksch E. Altersspezifische prinzipien der topischen therapie. Hautarzt. 2014;65:192-6.

140. Chaudhary A, Singh N. Herbo mineral formulations (rasaoushadhies) of ayurveda an amazing inheritance of ayurvedic pharmaceutics. Anc Sci Life. India. 2010;30:18-26.

141. Erhirhie EO, Emeghebo CN, Ilodigwe EE, Ajaghaku DL, Umeokoli BO, Eze PM, et al. Dryopteris filix-mas (L.) Schott ethanolic leaf extract and fractions exhibited profound anti-inflammatory activity. Avicenna J phytomedicine. Iran. 2019:9:396-409.

142. Ahmad M, Muhammad N, Mehjabeen JN, Ahmad M, Habib S. Pharmacological and biological evaluation of extracts from Gratiola officinalis L. (Scrophulariaceae). Pak J Pharm Sci. Pakistan. 2012;25:657-63.

143. Polukonova NV, Navolokin NA, Raikova SV, Masliakova GN, Bucharskaia AB, Durnova NA, et al. Antl-inflammatory, antipyretic and antimicrobial activity of flavonoid-containing extract of Gratiola officinalis L. Eksp Klin Farmakol. Russia (Federation). 2015;78:34-8.

144. Aviello G, Abenavoli L, Borrelli F, Capasso R, Izzo AA, Lembo F, et al. Garlic: empiricism or science? Nat Prod Commun [Internet]. United States; 2009:4 1785-96. Available from: https://www.ncbi.nlm.nih.gov/pubmed/20120123.

145. Hodge G, Davis S, Rice M, Tapp H, Saxon B, Revesz T. Garlic compounds selectively kill childhood pre-B acute lymphoblastic leukemia cells in vitro without reducing T-cell function: Potential therapeutic use in the treatment of ALL. Biol Targets Ther. 2008;2:143-9.

146. Aranceta J, Pérez Rodrigo C, Naska A, Vadillo VR, Trichopoulou A. Nut consumption in Spain and other countries. Br J Nutr. 2006;96:S3-11.

147. Sánchez-González C, Ciudad CJ, Noé V, Izquierdo-Pulido M. Health benefits of walnut polyphenols: An exploration beyond their lipid profile. Crit. Rev. Food Sci. Nutr. 2017. p. 3373-83.

148. Popovych V, Koshel I, Malofiichuk A, Pyletska L, Semeniuk A, Filippova O, et al. A randomized, open-label, multicenter, comparative study of therapeutic efficacy, safety and tolerability of BNO 1030 extract, containing marshmallow root, chamomile flowers, horsetail herb, walnut leaves, yarrow herb, oak bark, dandelion herb in the trea. Am J Otolaryngol. United States. 2019;40:265-73

149. Khiljee S, Rehman NU, Khiljee T, Loebenberg R, Ahmad RS. Formulation and clinical evaluation of topical dosage forms of Indian Penny Wort, walnut and turmeric in eczema. Pak J Pharm Sci. 2015;28:2001-7.

150. Kowalska M, Mendrycka M, Żbikowska A, Kowalska D. Assessment of a stable cosmetic preparation based on enzymatic interesterified fat, proposed in the prevention of Atopic dermatitis. Acta Pol Pharm - Drug Res. 2017;74:465-76

151. Cruz-Vega DE, Verde-Star MJ, Salinas-González N, Rosales-Hernández B, Estrada-García I, Mendez-Aragón P, et al. Antimycobacterial activity of Juglans regia, Juglans mollis, Carya illinoensis and Bocconia frutescens. Phyther Res. 2008;22:557-9.

152. Serakta M, Djerrou Z, Mansour-Djaalab H, Kahlouche-Riachi F, Hamimed S, Trifa W, et al. Antileishmanial activity of some plants growing in Algeria: Juglans regia, Lawsonia inermis and Salvia officinalis. African J Tradit Complement Altern Med AJTCAM. 2013;10:427-30.
153. Streliaeva A V, Polzikov V V, Prokina ES, Kurilov D V, Chebyshev N V, Shcheglova TA, et al. [Development of a new hydrocarbon extract from the medicinal raw material of Circassian walnut (Juglans regia) and study of its antiparasitic activity]. Med Parazitol (Mosk). 2011;28-31.

154. Gardiner P. Complementary, holistic, and integrative medicine: chamomile. Pediatr Rev. United States. 2007:28:e16-8.

155. Weizman Z, Alkrinawi S, Goldfarb D. Efficacy of herbal tea preparation in infantile colic. J Pediatr. 1993:122:650-2.

156. Glowania HJ, Raulin C, Swoboda M. [Effect of chamomile on wound healing--a clinical double-blind study]. Z Hautkr. Germany. 1987;62: 1262,1267-71.

157. Patzelt-Wenczler R, Ponce-Poschl E. Proof of efficacy of Kamillosan(R) cream in atopic eczema. Eur J Med Res. England. 2000;5:171-5.

158. Aertgeerts P, Albring M, Klaschka F, Nasemann T, Patzelt-Wenczler R, Rauhut $\mathrm{K}$, et al. [Comparative testing of Kamillosan cream and steroidal $(0.25 \%$ hydrocortisone, $0.75 \%$ fluocortin butyl ester) and non-steroidal (5\% bufexamac) dermatologic agents in maintenance therapy of eczematous diseases]. Z Hautkr. Germany. 1985;60:270-7.

159. Zargaran A, Borhani-Haghighi A, Salehi-Marzijarani M, Faridi $P$ Daneshamouz S, Azadi A, et al. Evaluation of the effect of topical chamomile (Matricaria chamomilla L.) oleogel as pain relief in migraine without aura: a randomized, double-blind, placebo-controlled, crossover study. Neurol Sci Off J Ital Neurol Soc Ital Soc Clin Neurophysiol. Italy. 2018; 39:1345-53.

160. Abdullahzadeh M, Matourypour P, Naji SA. Investigation effect of oral chamomilla on sleep quality in elderly people in Isfahan: a randomized control trial. J Educ Health Promot. India. 2017;6:53.

161. Javid A, Motevalli Haghi N, Emami SA, Ansari A, Zojaji SA, Khoshkhui M, et al. Short-course administration of a traditional herbal mixture ameliorates asthma symptoms of the common cold in children. Avicenna J phytomedicine. Iran. 2019;9:126-33

162. Rugge SD, Nielsen M, Jacobsen AS, Vang O, Jemec GBE. [Evidence of dermatological effects of chamomile]. Ugeskr Laeger. Denmark. 2010; 172:3492-6.

163. Samuelsen AB. The traditional uses, chemical constituents and biological activities of Plantago major L. A review. J Ethnopharmacol. Ireland. 2000;71:1-21.

164. Bazafkan MH, Hardani A, Afzal Zadeh MR, Amir Zargar A, Orazi Zadeh M, Hemmati AA, et al. Wound healing effect of an ointment made from a mixture of brassica oleracea var, Punica granatum, and Plantago major $\mathrm{L}$ Extracts in Rats. Jentashapir J Heal Res. Kowsar. 2014;5:e21877.

165. Ashkani-Esfahani S, Khoshneviszadeh M, Noorafshan A, Miri R, Rafiee S, Hemyari $\mathrm{K}$, et al. The healing effect of plantago major and aloe vera mixture in excisional full thickness skin wounds: Stereological Study. World J Plast Surg. Iran. 2019:8:51-7.

166. Matev M, Angelova I, Koichev A, Leseva M, Stefanov G. [Clinical trial of a Plantago major preparation in the treatment of chronic bronchitis]. Vutr Boles. Bulgaria. 1982;21:133-7.

167. Kartini PS, Thongpraditchote S, Siripong P, Vallisuta O. Effects of Plantago major extracts and its chemical compounds on proliferation of cancer cells and cytokines production of lipopolysaccharide-activated THP-1 macrophages. Pharmacogn Mag. India. 2017;13:393-9.

168. Türel I, Ozbek H, Erten R, Oner AC, Cengiz N, Yilmaz O. Hepatoprotective and anti-inflammatory activities of Plantago major L. Indian J Pharmacol. Medknow Publications. 2009:41:120-4.

169. Gomez-Flores R, Calderon CL, Scheibel LW, Tamez-Guerra P, RodriguezPadilla C, Tamez-Guerra R, et al. Immunoenhancing properties of Plantago major leaf extract. Phytother Res. England. 2000;14:617-22.

170. Ponce-Macotela M, Navarro-Alegria I, Martinez-Gordillo MN, Alvarez-Chacon R. [In vitro effect against Giardia of 14 plant extracts]. Rev Invest Clin. Mexico. 1994;46:343-7.

171. Doan DD, Nguyen NH, Doan HK, Nguyen TL, Phan TS, van Dau N, et al. Studies on the individual and combined diuretic effects of four Vietnamese traditional herbal remedies (Zea mays, Imperata cylindrica, Plantago major and Orthosiphon stamineus). J Ethnopharmacol. Ireland. 1992;36:225-31.

172. Pantu ZC. Plantele cunoscute de poporul roman. II. Bucuresti: Editura Casei Scoalelor; 1929

173. Dragulescu R. Expresia latinitătii în fitonimia românească din sudul Transilvaniei. Transilvania. 2019;9:64-72.

174. Soelberg J, Davis O, Jäger AK. Historical versus contemporary medicinal plant uses in the US Virgin Islands. J Ethnopharmacol [Internet]. 2016/07/01. 
Ireland; 2016;192:74-89. Available from: https://www.ncbi.nIm.nih.gov/ pubmed/27377341.

175. Siqueira BVL, Sakuragui CM, Soares BE, de Oliveira DR. The rise of medicalization of plants in Brazil: a temporal perspective on vernacular names. J Ethnopharmacol [Internet]. 2018/06/19. Ireland; 2018;224:535-40. Available from: https://www.ncbi.nlm.nih.gov/pubmed/29933011.

176. Dragulescu R. Analysis of the connotative and denotative meanings of the term "dragon" (balaur) as it appears in the romanian phytonymy. J Rom Lit Stud. 2017;10:104-10.

177. NODEX. Noul dicționar explicativ al limbii române. Bucuresti, Romania: Editura Litera International; 2002.

178. Marian SF. Mitologia daco-romană_Samca. Amicul Fam. 1880;9/21 marti.

179. Marian SF. Mitologia daco-romană—Samca. Amicul Fam. 1880;23 martie/.

180. Mulinari S. The specificity triad: notions of disease and therapeutic specificity in biomedical reasoning. Philos Ethics Humanit Med [Internet]. BioMed Central; 2014;9:14. Available from: https://www.ncbi.nIm.nih.gov/ pubmed/25326797.

181. Johnson AL, MCLeish AC, Shear PK, Privitera M. Panic and epilepsy in adults: a systematic review. Epilepsy Behav [Internet]. 2018/06/22. United States; 2018;85:115-9. Available from: https://www.ncbi.nlm.nih. gov/pubmed/29940374.

182. Eccles R, Wilkinson JE. Exposure to cold and acute upper respiratory tract infection. Rhinology. International Rhinologic Society. 2015;53:99-106.

183. Ameri A, Metzmeier P, Peters T. Frequency-dependent inhibition of neuronal activity by lappaconitine in normal and epileptic hippocampal slices. Br J Pharmacol. England. 1996:118:577-84.

184. Ameri A. Inhibition of rat hippocampal excitability by the plant alkaloid 3-acetylaconitine mediated by interaction with voltage-dependent sodium channels. Naunyn Schmiedebergs Arch Pharmacol. Germany. 1997:355:273-80.

185. Ameri A. Structure-dependent inhibitory action of the Aconitum alkaloids 14-benzoyltalitasamine and talitasamine in rat hippocampal slices. Naunyn Schmiedebergs Arch Pharmacol. Germany. 1998;357:585-92.

186. Awad R, Muhammad A, Durst T, Trudeau VL, Arnason JT. Bioassay-guided fractionation of lemon balm (Melissa officinalis L.) using an in vitro measure of GABA transaminase activity. Phytother Res. England. 2009;23:1075-81.

187. Jager AK, Gauguin B, Adsersen A, Gudiksen L. Screening of plants used in Danish folk medicine to treat epilepsy and convulsions. J Ethnopharmacol. Ireland. 2006;105:294-300.

188. Tomioka H, Namba K. [Development of antituberculous drugs: current status and future prospects]. Kekkaku. Japan. 2006;81:753-74.

189. Marian SF. Botanica romaneasca. Bucuresti, Romania: Paidea; 2000.

\section{Publisher's Note}

Springer Nature remains neutral with regard to jurisdictional claims in published maps and institutional affiliations.

Ready to submit your research? Choose BMC and benefit from:

- fast, convenient online submission

- thorough peer review by experienced researchers in your field

- rapid publication on acceptance

- support for research data, including large and complex data types

- gold Open Access which fosters wider collaboration and increased citations

- maximum visibility for your research: over $100 \mathrm{M}$ website views per year

At $\mathrm{BMC}$, research is always in progress.

Learn more biomedcentral.com/submissions 